\begin{tabular}{|l|c|c|c|}
\hline Eiszeitalter und Gegenwart & $\mathbf{5 5}$ & $\begin{array}{c}122-148 \\
22 \mathrm{Abb}, 2 \mathrm{Tab} .\end{array}$ & Hannover 2005 \\
\hline
\end{tabular}

\title{
Middle Pleistocene bats (Mammalia: Chiroptera) from the Yarimburgaz Cave in Turkish Thrace (Turkey)
}

\author{
Christa Lindenau $^{*}$
}

Keywords: Chiroptera, Rhinolophidae, Vespertilionidae, Middle Pleistocene, Turkey, Turkish Trace, Yarimburgaz Cave

\begin{abstract}
The Yarimburgaz Cave near Bosporus is an important Middle Pleistocene fossil site both in terms of Archeology and Paleontology in the northeast Mediterranean, containing the richest bat fauna of that time.

There are at least 14 and possibly as many as 16 species of the genera Rhinolophus, Myotis, Plecotus, and Miniopterus present in this locality. The identification is based on the morphology of skulls, jaws, and humeri. The cave contains three sedimentary cycles. Cycle I is the oldest unit and produces most of the species, eight, with Rhinolophus mehelyi and Myotis blythii the most frequent. The presence of these species suggests a Mediterranean climate with cool, rainy winters and hot, moderately dry summers (KRYŠTUfEK \& Vohralík 2001). In cycle II very few fossils were found. Cycle III contains fewer individuals than cycle I with only six taxa represented. Myotis blythii and Miniopterus schreibersi are the dominating species. Given the presence of the rodents and lagomorphs of the Yarimburgaz Cave, a heterogeneous climate with changing colder, dryer, but also warmer phases which are indicated by the bats, can be supposed.
\end{abstract}

[Mittelpleistozäne Chiroptera (Mammalia) aus der Yarimburgaz-Höhle in Türkisch Thrazien (Türkei)]

* Anschrift des Verfassers: Dipl.-Geol. Christa Lindenau, Institut für Paläontologie, Universität Bonn, Nussallee 8, D-53115 Bonn, c.lindenau@unibonn.de
Kurzfassung: Die Yarimburgaz-Höhle am Bosporus ist die wichtigste Fundstelle für die mittelpleistozäne Archäologie und Paläontologie im nordöstlichen Mittelmeerraum und beinhaltet in diesem Zeitraum die reichste Fledermausfauna der Region. Aus der Lokalität werden hier die Chiropteren anhand von Crania, Mandibulae und Humeri untersucht. Es sind mindestens 14, eventuell bis zu 16 Arten aus den Gattungen Rhinolophus, Myotis, Miniopterus und Plecotus vorhanden, wodurch die bisherige Fossilfauna um weitere neun bis elf Arten ergänzt wird. Von den drei Sedimentationszyklen enthält der älteste, Zyklus I, die meisten Fledermausfunde. Unter den acht verschiedenen Arten sind Rhinolophus mehelyi und Myotis blythii am häufigsten vertreten und weisen auf mediterranes Klima mit kühlen, regnerischen Wintern und heißen, trockenen Sommern hin (Kryštufek \& Vohralík 2001). Aus Sedimentationszyklus II sind außer einer Mandibel von $R$. mehelyi keine weiteren Funde überliefert. Zyklus III beinhaltet mit insgesamt sechs Taxa wesentlich weniger Funde als Zyklus I. Darunter sind Myotis blythii und Miniopterus schreibersi die dominierenden Arten. Verglichen mit den Rodentia und Lagomorpha aus der Yarimburgaz-Höhle, die als Einwanderer des südrussischen Steppengürtels mehrere kälteangepaßte Arten umfassen und rezent nicht mehr in Thrazien vorkommen, kann ein inhomogenes Klima angenommen werden, mit wechselweise kühleren, trockeneren, aber auch wärmeren Phasen, welche durch die Fledermäuse angedeutet werden.

\section{Introduction}

Intensive excavations in the Yarimburgaz Cave yielded more than 1600 artifacts from the Mid- 
dle Pleistocene, predominantly from the upper two meters of sediments from the entrance area of the lower cave (Howell \& ARSEBÜCK 1989; KuHn 1995). Large mammals are also excavated with the cave bear Ursus deningeri being the most frequent. Within the carnivores Vulpes, Canis, Panthera, Felis, and Crocuta are also present. The herbivores contain Equus, Sus, Dama, Cervus, Megaloceros, Capreolus, Bos/ Bison, Gazella, and Capra (STINer 1995). This fauna may represent the hunting activity of Early man, but others species like the cave bear most probably used the cave for hibernation. The small mammal fauna is not as rich and represented by some Insectivora, Rodentia (i.a. Scioridae, Murinae, Cricetinae, Arvicolinae), and Lagomorpha (Santel \& Koenigswald i998). Bats make up the biggest portion within the small mammals. Ecological conclusions will be drawn on the basis of recent exponents ecology. Here we aim to interpret the paleoclimatic conditions present and these will be compared with the ecological data derived from the Rodentia and Lagomorpha SAntel \& Koenigswald (1998) described from the same locality. This will allow us to test if both faunal groups indicate the same climatic conditions. As bats are rare in the fossil record this Middle Pleistocene is a highly significant location.

\section{Locality}

The Yarimburgaz Cave is located $20 \mathrm{~km}$ west of Istanbul in Turkish Thrace and belongs to a vast complex developed in Middle Eocene of Lutetian limestone. The cave system contains two chambers, the lower one continues for about $500 \mathrm{~m}$ the other for some $50 \mathrm{~m}$. These two chambers are connected through a ramp like passage but each has its own entrance (fig. 1). For a long time part of the cave was used for various purposes. First scientific explorations were established during 1964-1965. In 1986 M. ÖZDOĞAn made a systematic survey in the upper cave. During 1988-1990 C. Howell and G. ARSEBüCK carried out the main excavations in the lower chamber, producing the bat fauna described here. All excavations were pursued in the entrance area.

The sediments filling the lower cave were excavated in various unconnected trenches (P-90, S89, T-89, A-71 \& V-88, Y-88, U-88, R-90, and Z-88) roughly following the midline of the cave from north to south (fig. 1;2). These trenches were designated with a capital letter followed by the number of the year the excavation took place, except for trench A-71, which was excavated by ÖZDOĞAN in 1986. The letters Q, W, and $\mathrm{X}$ do not occur because they do not exist in Turkish (FarRand \& McMaHon 1997).

The level numbers in each trench were assigned by the excavators independently of those in the other trenches, except for trenches S-89 and T89, which were dug simultaneously (FARRAND \& McMahon 1997). Therefore a correlation of the different levels was not possible and there are no data about the thickness of the levels. However, the excavation levels were grouped by FarRand \& McMahon (1997) into lithostratigraphic units designated Stratum $\mathrm{R}$ through Stratum Z (from bottom to top) from three sedimentary cycles (fig. 2, tab. 1). In this case, additional letters $\mathrm{W}$ and $\mathrm{Z}$ were used, so one has to be certain the letter used for classification are correctly assigned to either the excavation square or to a stratigraphic unit. Only square $U$ could not be correlated because it was very shallow, over bedrock and its stratigraphy was not informative (Farrand \& McMaHon 1997).

The deepest trench, A-71 \& V-88, was dug five meters below the surface without reaching bedrock. However below two meters no artifacts or bones were found (FARRAND \& MCMaHoN 1997).

Depending on the position of the square there variations can be found in the composition of 


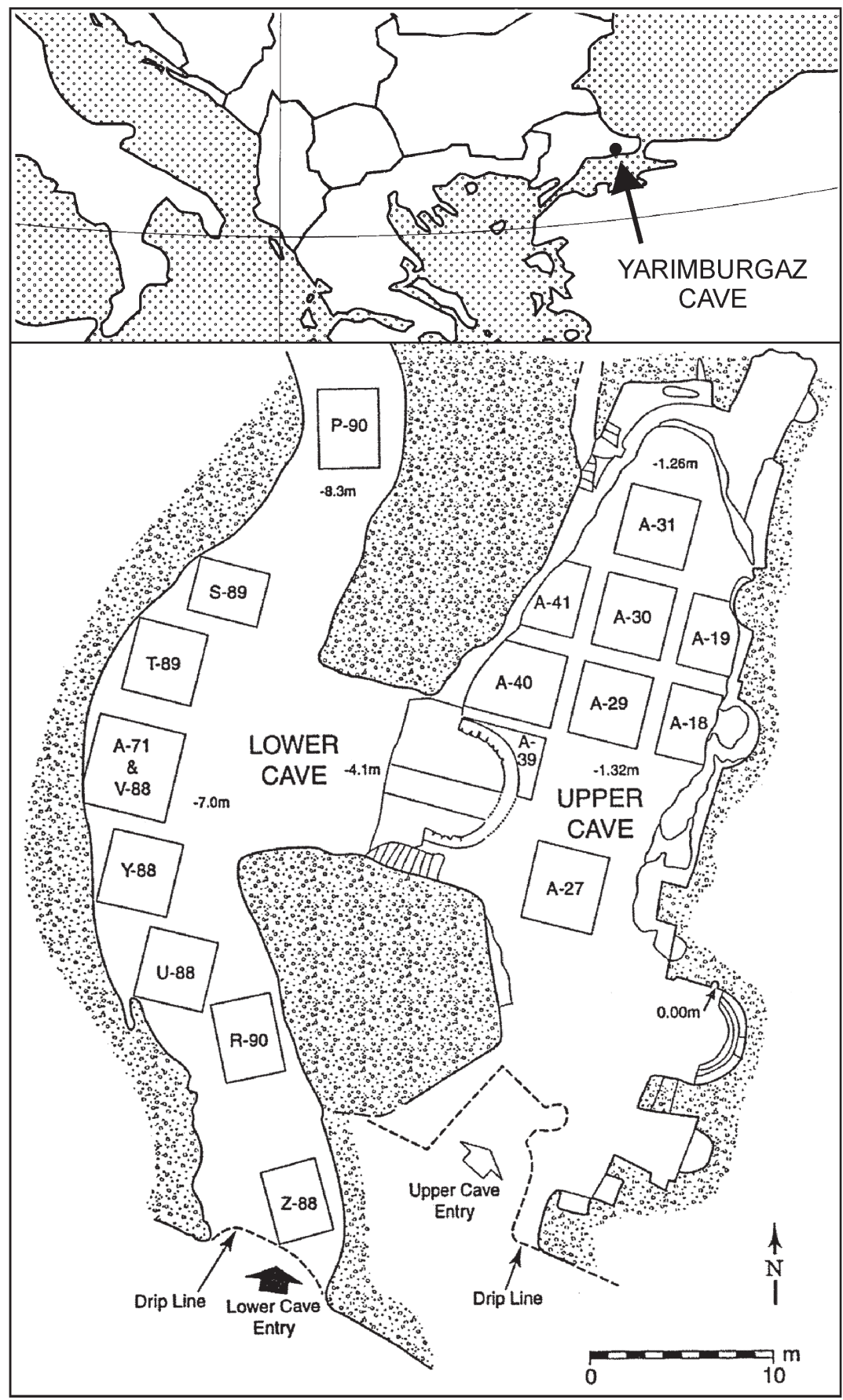

Fig. 1: Map of the entrance area of Yarimburgaz Cave with openings to the upper and lower chamber including the squares (after Farrand \& McMahon I997).

Abb. 1: Karte des Eingangsbereiches der Yarimburgaz-Höhle mit den Öffnungen zur oberen und unteren Kammer und Grabungsquadraten (nach Farrand \& McMahon I997). 
里

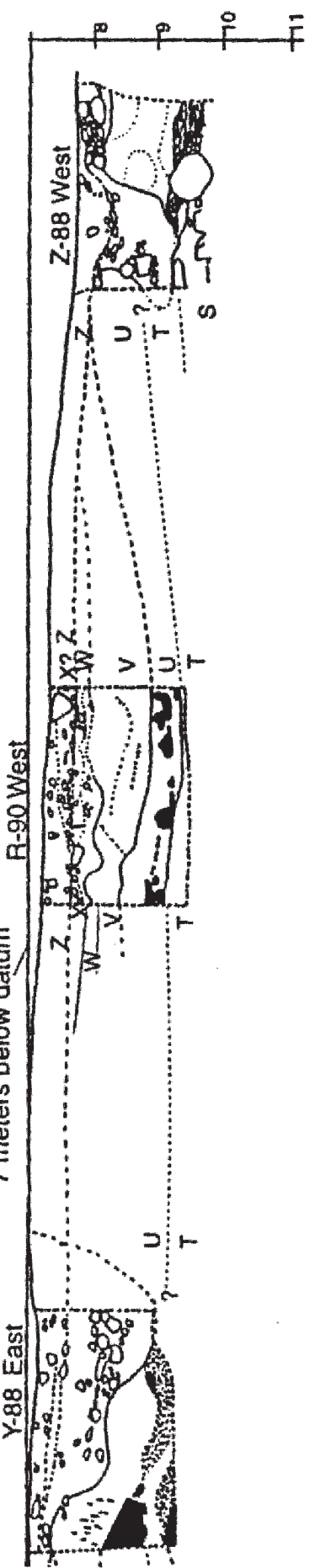

(n)
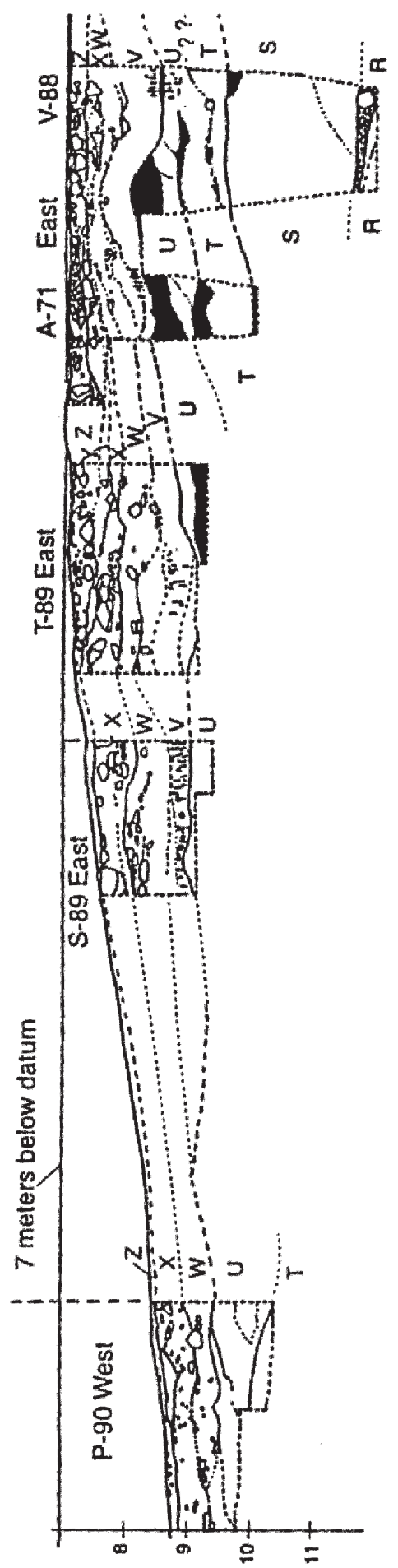

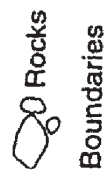

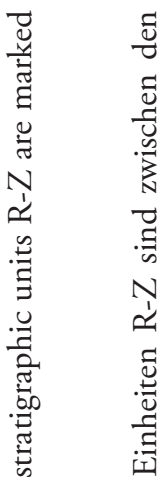

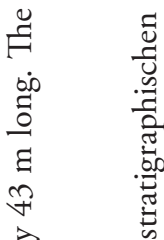

苞

है

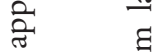

范

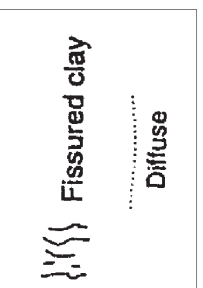

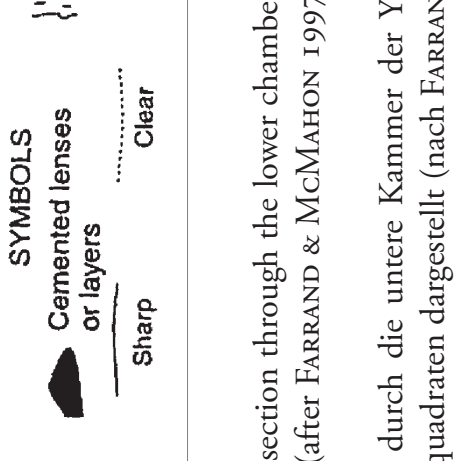

节

鬲 क्ष

कू

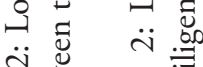

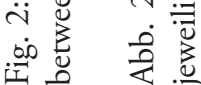


Tab. 1: Correlation of the excavation levels grouped into lithostratigraphic units designated Stratum $\mathrm{R}$ through Stratum Z (from bottom to top) from three sedimentary cycles.

Tab. 1: Korrelation der Horizonte der einzelnen Grabungsquadrate in die stratigraphischen Einheiten Schicht R bis Schicht Z (vom Liegenden zum Hangenden) aus drei Sedimentationszyklen.

\begin{tabular}{|c|c|}
\hline \multirow{3}{*}{$\begin{array}{c}\text { sedimentary cycle III } \\
\text { (youngest) }\end{array}$} & Stratum Z (= layer Z) \\
\cline { 2 - 2 } & Stratum Y (= layer Y) \\
\cline { 2 - 2 } & Stratum X (= layer X) \\
\cline { 2 - 2 } & Stratum W (=layer W) \\
\hline \multirow{3}{*}{ sedimentary cycle II } & Stratum V (= layer V) \\
\cline { 2 - 2 } & Stratum U (= layer U) \\
\cline { 2 - 2 } & Stratum T (= layer T) \\
\hline $\begin{array}{c}\text { sedimentary cycle I } \\
\text { (oldest) }\end{array}$ & Stratum S (= layer S) \\
\cline { 2 - 2 } & Stratum R (= layer R) \\
\hline
\end{tabular}

clay, cemented layers, and rocks. Furthermore, many boundaries are diffuse.

The cave sediments contain deposits from Lower Paleolithic to Byzantine times, but the lower chamber was disturbed by illicit excavators so that Middle/Upper Paleolithic and Chalcolithic are missing, although present in the upper cave.

\section{The bat fauna}

There are few fossil localities providing Pleistocene bats from the Mediterranean. Fossil bats are known from some islands, but there are very few species and within these most are endemic (STORCH I974). As megachiropterans (flying foxes) are distributed only in tropical and subtropical regions of the Old World and missing in America, this fossil record contains exclusively bats (Schober \& Grimmberger i 998).

The excavations from Yarimburgaz Cave in Turkish Thrace provided chiropterans from three cycles (tab. 1). Other small mammals (insectivores, rodents and lagomorphs) from this
Tab. 2: Systematic classification of the identified chiropterans based on McKenna \& Bell (2000).

Tab. 2: Systematische Gliederung der untersuchten Chiropteren nach McKenna \& Bell (2000).

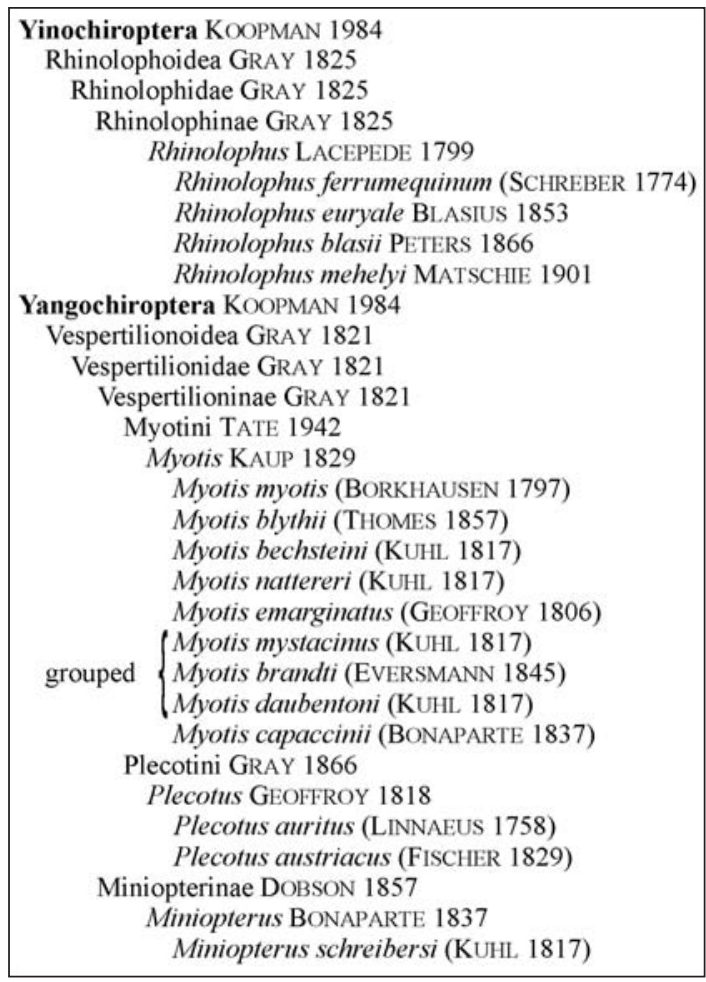

cave have been previously described by SANTEL \& Koenigswald (1998).

The rodents were accumulated most probably by owl pellets, whereas the bats may have used the cave as a day roost. Therefore the taphogenesis is caused by either accumulation by predators and natural death in the cave. Depending on function, different dwellings can be distinguished: roosts which are used daily or as a transient roost, mating roost, maternity roost and winter roost (GEBHARD I 997; SCHObER \& Grimmberger 1998). Generally, the first three are called summer roosts and can be in tree hollows or caves, whereas hibernating bats are normally found in caves. Some of the chiropterans may have used the cave seasonally, only in summer, whereas others may have used the cave to 


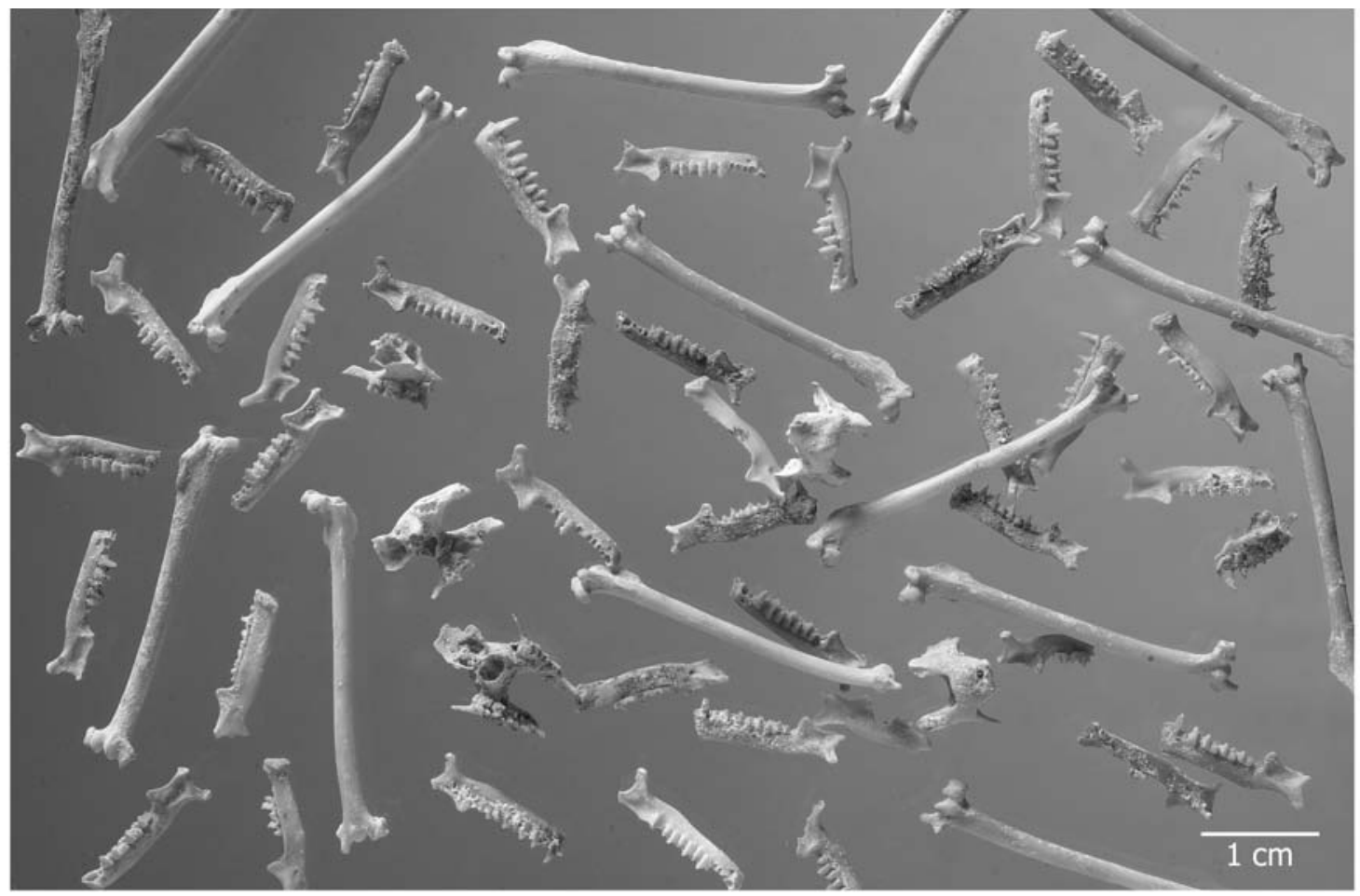

Fig. 3: View of the material composed of upper and lower jaws and humeri, considering as example of Rhinolophus mehelyi.

Abb. 3: Überblick über das Material bestehend aus Ober- und Unterkiefern sowie Humeri am Beispiel von Rhinolophus mehelyi.

hibernate. The Yarimburgaz Cave is presumably a year-round dwelling concerning bats.

For climatic reconstruction it would be useful to separate species occurring only during summer from those present year round. However, such a discrimination cannot be done in the fossil record.

Recent Microchiroptera are distributed world wide with 17 families, 150 genera, and 808 species, and are absent only in polar regions and on some isolated oceanic islands (NowaK 1999). Most are insectivorous, but in the tropics some are food specialists, which feed on fruits, leaves, nectar, pollen, fishes, other small vertebrates, or blood (Koopman i 994, NowaK 1999).

Both infraorders of microchiropterans from Yarimburgaz Cave could be verified, Yinochi- roptera (premaxillae almost never fused with maxillary) and Yangochiroptera (premaxillaries always fused with maxillaries in adults). The first is represented by the family Rhinolophidae, including four species of one genus (tab. 2). The Yangochiroptera are represented by three genera and ten to twelve species of the Vespertilionidae (tab. 2).

The material consists of 229 fragmentary rostra and maxillae, 1562 mandibles, and 717 humeri were identified. Fig. 3 provides a general impression of the preserved material. Light sedimentary incrustation of the studied objects was removed with an insect needle. Further material is damaged and identification beyond Microchiroptera is obviated. Apart from the humeri no further postcranial material was analyzed, 
because there is a great concordance in bone size and characteristics. Furthermore the skeleton is gracile so preservation is limited.

Early Pleistocene material from Deutsch Altenburg (DA 28, Austria) was available for comparisons from the Institute of Paleontology, University of Vienna (UWPI). Recent bat material was consulted for identification from the collections of the Forschungsinstitut und Naturmuseum Senckenberg (SMF), Frankfurt, Zoologisches Forschungsinstitut und Museum Alexander Koenig (ZFMK), Bonn, and from the Institute of Paleontology Bonn (IPB). At present the Yarimburgaz chiropterans are preserved at the IPB under the stated reference number (Yar). For identification of skull elements the following literature was used: Schober \& Grimmberger (I 998), Görner \& Hackethal (i988), and Kowalski \& Ruprecht (i98 I). A special key for jaws can be found in Ruprecht (i987). Felten, Helfricht \& Storch (1973) created a key to define the distal humerus epiphysis.

Accurate species determination was achieved in two ways: through measurements of teeth and humeri, as well as by morphological characteristics. No difference in size or shape between the bats from Yarimburgaz Cave compared with the Early Pleistocene specimens from DA 28 and with the recent samples could be detected. Therefore all microchiropterans from Yarimburgaz Cave belong to species still existing today. Caused by the great variation in size and characteristics of some bats it was not always possible to identify the species. These unidentifiable species are grouped and discussed after the species description.

\section{Osteology and teeth}

The skeleton of the microchiropterans is very gracile, an adaptation to flight, with the arm and hand being elongated. The humerus is strongly developed and the forearm, consisting of radius and an extreme reduced ulna, is enormously elongated. The metacarpals and phalanges of the second to the fifth finger are elongated to thin torque arms. The cartilaginous tips of the fingers end T-shaped at the margin of the flight membrane. Only the thumb is still a flexible grabbing-tool and has a claw (NeuweIler, 1993).

Only a few weeks after birth the skull is coadunated and sutures of single skull elements are not visible. Therefore a rough classification in cranium and rostrum results.

It is unclear, which of the incisivi and premolars are reduced. After Handley (1959) the reduction took place on the I3 and the second upper and lower premolar. The status of discussion is given in Rachel (1984). According to HandLEY (1959) in this paper the eutherian dental formula is modified to I 1 (2)/i 12 (3), C 1/c 1 , P 1 (3) 4/p 1 (3) 4, M 12 3/m 12 3. The teeth of the positions in brackets can be absent.

\section{Determination of the material}

Rhinolophidae Gray, I825 Horseshoe Bats Rhinolophus LACÉPÈDE 1799

There is a single genus - Rhinolophus - with 64 living species (KoOpMan 1994).

The nasal region of the skull is clearly bulged out. The premaxilla builds a fragile intermaxilla which is only linked to the palatinum by connective tissue. Therefore the intermaxilla cannot be conserved in fossil skulls but remains a huge palatine incision. The mandible is conspicuously long and flat, the most distinguishing character is the extremely flat processus (proc.) coronoideus.

The first teeth within the upper jaw are the large, strongly curved canines as the incisivi situated on the palatine are not preserved. The P1 is mostly reduced and placed buccally. The P4 is large and distally has a sharp crista. 


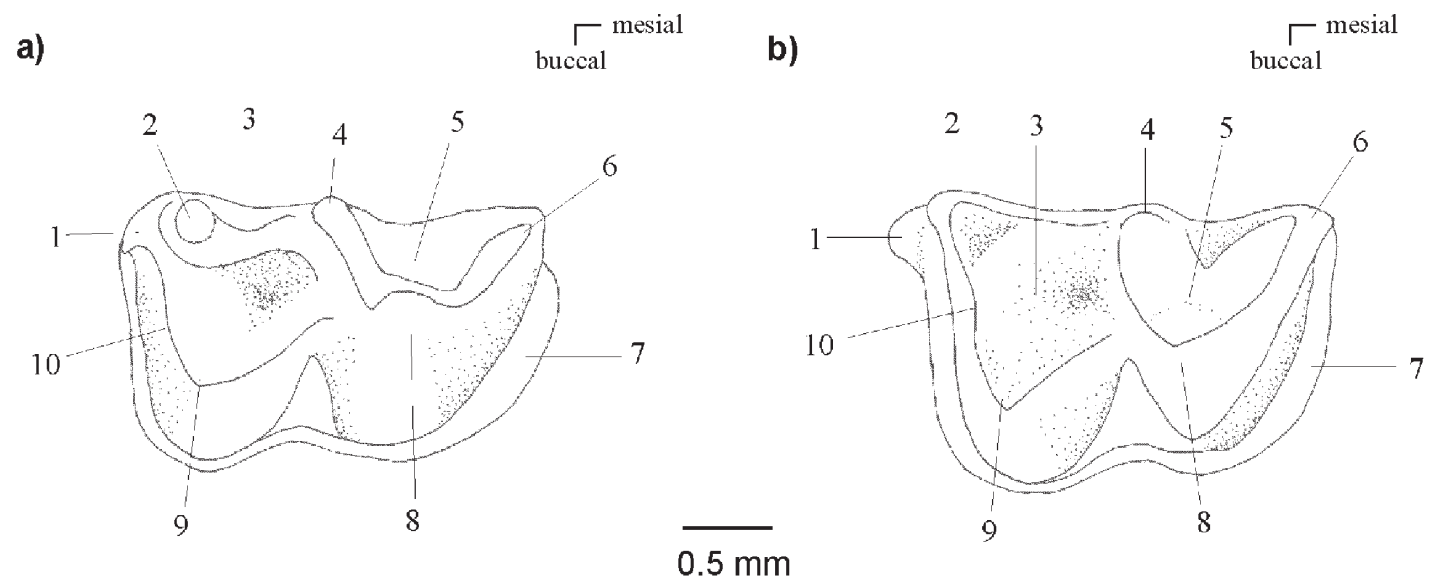

nyctalodont type of dentition: entoconid and hypoconid are linked by the postcristid (Rhinolophus ferrumequinum, Yar 1200) myotodont type of dentition: hypoconulid and hypoconid are linked by the postcristid (Myotis myotis, Yar 1201)

Fig. 4: Right $\mathrm{m} 1$ in occlusal view of a) Rhinolophus ferrumequinum (Yar 1200) and b) Myotis myotis (Yar 1201). Terminology: 1. hypconulid, 2. entoconid, 3. talonid, 4. metaconid, 5. trigonid, 6. paraconid, 7. cingulum, 8. protoconid, 9. hypoconid, 10. postcristid.

Abb. 4: Rechter $\mathrm{m} 1$ in Occlusalansicht von a) Rhinolophus ferrumequinum und b) Myotis myotis. Terminologie: 1. Hypconulid, 2. Entoconid, 3. Talonid, 4. Metaconid, 5. Trigonid, 6. Paraconid, 7. Cingulum, 8. Protoconid, 9. Hypoconid, 10. Postcristid.

On M1-2 the hypocone is well developed and curved in mesio-distal direction. The M 3 is slightly smaller than the M2, the reduction affects mainly metastyle and hypocone. In the lower jaw the incisivi are closely spaced. Their crown is three-parted and spatulate. The $\mathrm{c}$ is very high and surrounded by a broad cingulum. Two lateral ridges frame a broad concave and distal directed plane. The $\mathrm{p} 1$ is relatively small. The $\mathrm{p} 3$ is maintained only as a diminutive tooth at the buccal outside of the tooth row. In opposite, the $\mathrm{p} 4$ is relatively large and builds three distinct ridges. The morphology of $\mathrm{m} 1-\mathrm{m} 3$ is nyctalodont (fig. 4).

The distal epiphysis of the humerus is characterized by a long spikelike processus styloides as well as by a very broad expanded epitrochlea and epicondylus. A deep incisur is located between trochlea and condylus.

Rhinolophus ferrumequinum (SCHREBER I774), Greater Horseshoe Bat

cycle I: 1 rostrum, 4 mandibles, 11 humeri; cycle III: 2 maxillae, 1 mandible, 1 humerus; uncorrelated: 1 rostrum, 3 maxillae, 14 mandibles, 5 humeri

R. ferrumequinum is the largest European Rhinolophus-species and it can easily be identified by its dimensions.. The P1 of the upper jaw is very small and shifted buccally so the canine and the P4 are in contact. Similar to that the p3 in the lower jaw is enormously reduced and displayed buccally beyond the tooth row. The molars are nyctalodont (fig. 4).

The distal epiphysis of the humerus has a width 
a)

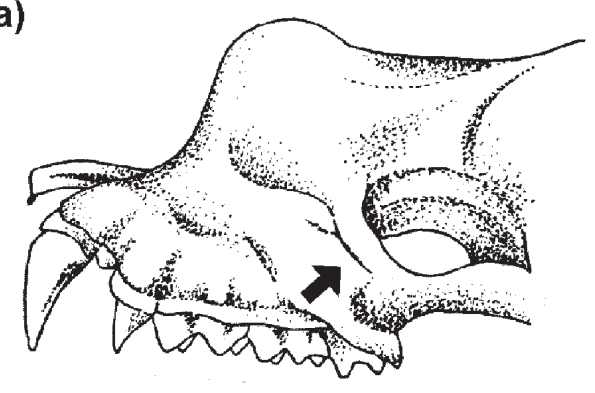

R. euryale

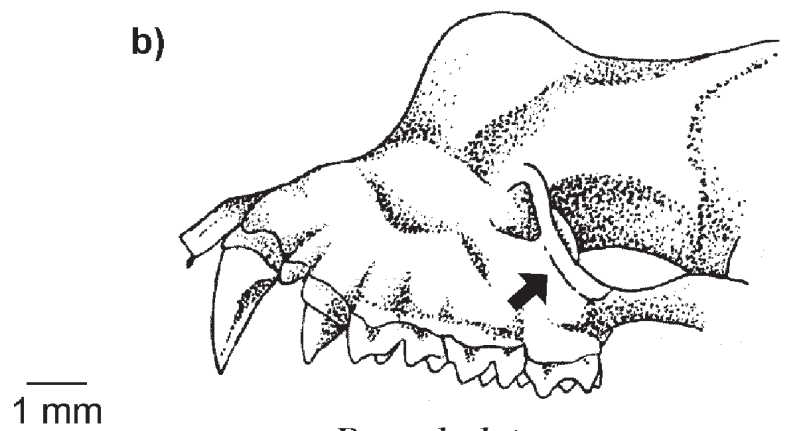

R. mehelyi

Fig. 5: Comparison of the skulls of Rhinolophus euryale and Rhinolophus mehelyi (after SCHовER \& GRIMMBERGER 1998).

Abb. 5: Vordere Schädelhälfte von Rhinolophus euryale und Rhinolophus mehelyi im Vergleich (nach ScHOBER \& GRIMMBERGER 1998).

a)

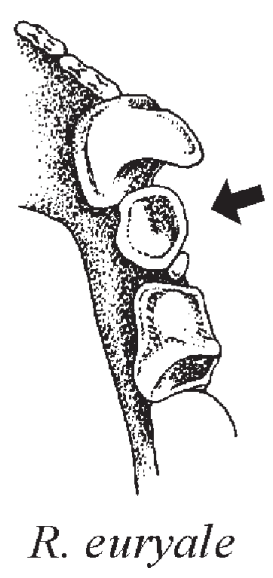

b)

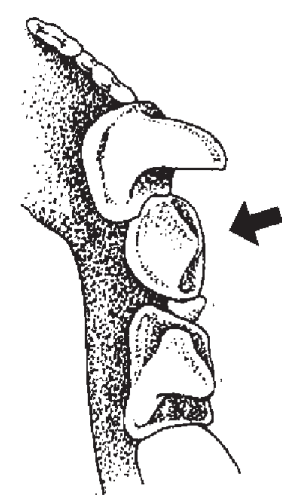

R. blasii

Fig. 6: Lower toothrow of Rhinolophus euryale and Rhinolophus blasii. In R. euryale the $\mathrm{p} 1$ takes less than $50 \%$ of the plane of $\mathrm{p} 4$, in $R$. blasii the proportion of the plane is greater than 50\% (after ScHOBER \& GrimMBerger 1998).

Abb. 6: Untere Zahnreihe von Rhinolophus euryale und Rhinolophus blasii. Bei $R$. euryale nimmt der p1 weniger als 50\% der Fläche des p 4 ein, bei $R$. blasii liegt der Anteil der Fläche über 50\% (nach SсHOBER \& GrimMBerger 1998). 

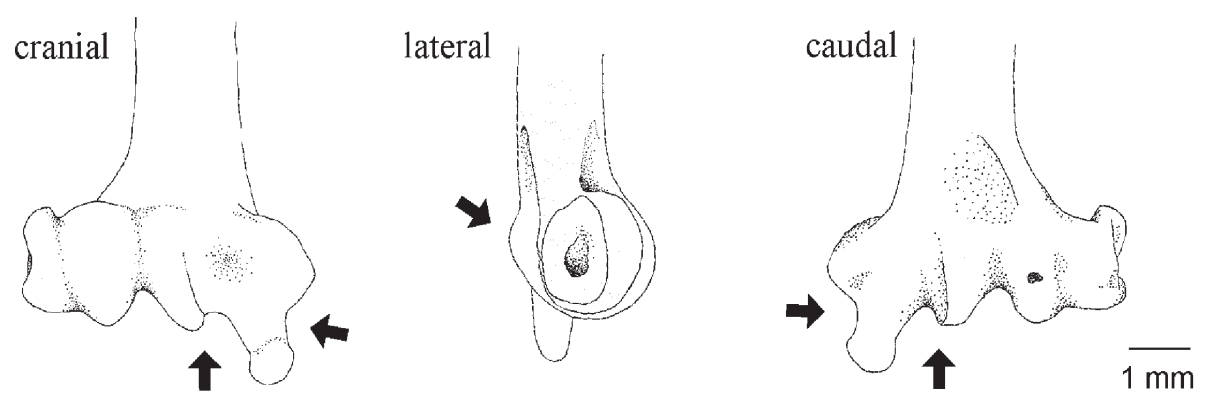

Fig. 7: Distal epiphysis of the humerus of Rhinolophus euryale (Yar 1155) in cranial, lateral, and caudal view.

Abb. 7: Distale Epiphyse des Humerus von Rhinolophus euryale (Yar 1155) in cranialer, lateraler und caudaler Ansicht.

of about $5 \mathrm{~mm}$ between epitrochlea and epicondylus which is found in no other rhinolophid species.

Rhinolophus euryale BLAsIUs I853, Mediterranean Horseshoe Bat

cycle I: 4 humeri; uncorrelated: 1 humerus

The most striking characteristic on the skull is an ossified bar between the foramen (for.) infraorbitale and the orbita. This bar is short and relatively broad (fig. 5). The P1 is located buccally at the border of the tooth row and is constricted by the spiky $\mathrm{C}$ and the P4. The M3 is slightly reduced. In the lower jaw the crownplane of the p 1 achieves a maximum of $50 \%$ of the plane of the p4 (fig. 6). The p3, which lies between them, is shifted buccally far beyond the tooth row. Its peak reaches the cinguli of the remaining premolars.

On the distal epiphysis of the humerus an incisur is situated at the transition of the proc. styloides to the epitrochlea in cranial and caudal view (fig. 7). The proc. styloides is relative slender. In the same views the trochlea forms a distinct edge towards distal. Looking at the caudal outline of the trochlea no sharp edge is developed in lateral view.

Because there are great analogies of $R$. euryale with and $R$. mehelyi concerning characteristics and size only five humeri could be clearly identified. This problem will be discussed after the description of $R$. blasii and $R$. mehelyi and similar species will be combined as one group.

Rhinolophus blasii Peters I866, Blasius's Horseshoe Bat

cycle I: 1 mandible, 8 humeri; uncorrelated: 3 humeri

The skull exhibits a smooth occipital depression. The ossified bar between the for. infraorbitale and the orbita is relatively short and narrows slightly to the middle. The P1 and P4 are often separated through a diastema. In the lower jaw the crown-plane of the $\mathrm{p} 1$ takes not less than $50 \%$ of the plane of p4 (fig. 6). The p3 in-between is squashed in and strongly reduced.

The top of the proc. styloides on the distal epiphysis of the humerus is rounded towards medial (fig. 8). The transition of the proc. styloides towards the epitrochlea is shallow in cranial and caudal view. Based on the smaller width of the epiphysis at an average of $4 \mathrm{~mm}$ in addition to the other characteristics the humeri of $R$. blasii can easily be identified.

Only one lower mandible could be recognized for $R$. blasii. Here the $\mathrm{p} 4$ is still preserved and 


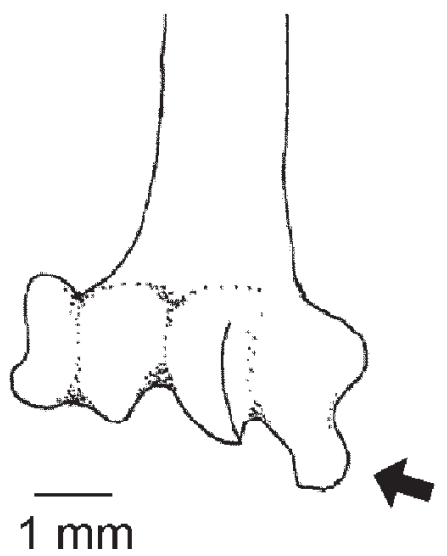

Fig. 8: Distal epiphysis of the humerus of Rhinolophus blasii (Yar 1049) in cranial view. The top of the proc. styloides is rounded towards medial.

Abb. 8: Distale Epiphyse des Humerus von Rhinolophus blasii (Yar 1049) in Cranialansicht. Die Spitze des Proc. styloides ist nach medial abgerundet.

affords accurate identification. Analogies with other species will be discussed within the following group.

\section{group Rhinolophus euryale-blasii}

cuncorrelated: 7 mandibles

There are very few characteristics of the skull and mandible to separate these two mediumsized species.

One possibility would be the parietal- / occipital-region of the skull. It runs straight in $R$. euryale and shows an incisur in $R$. blasii. But no skull with this attribute or appropriate size is preserved from Yarimburgaz Cave. Concerning the lower jaw both species can be separated by the proportion of the crown-plane of $\mathrm{p} 1$ to $\mathrm{p} 4$. The plane of $\mathrm{p} 1$ reaches a maximum of $50 \%$ of the $\mathrm{p} 4$ in $R$. euryale, whereas in $R$. blasii the plane of $\mathrm{p} 1$ reaches a minimum of $50 \%$ of the p4 (fig. 6). As only in one lower jaw the p1 is preserved, further jaws of similar size could not be identified to species level.

Rhinolophus mehelyi Matschie I 90I, Mehely's Horseshoe Bat cycle I: 28 rostra, 15 maxillae, 214 mandibles, 189 humeri; cycle II: 1 maxilla, 1 mandible, 4 humeri; cycle III: 2 maxillae, 1 rostrum, 3 maxillae, 7 mandibles, 5 humeri; surface: 1 rostrum; uncorrelated: 7 rostra, 63 maxillae, 567 mandibles, 173 humeri

The most characteristic feature of the skull is supposed to be the thin ossified bar between the for. infraorbitale and the orbita (fig. 5). Within no other species the bone bar is that slender. The P4 is relatively large and its peak overtops the molars. The p3 in the lower jaw is rudimental and pushed buccally out of the tooth row by p1 and p4.

At the distal epiphysis of the humerus the proc. styloides is relatively broad and laminar in cranial view. Its transition to the epitrochlea is fordable (fig. 9). The trochlea builds distally a sharp ridge which is clearly to see in cranial and caudal view. In lateral view the trochlea builds a projecting and angled outline. The average width of the epiphysis is $4.5 \mathrm{~mm}$ (FELTEN et al. 1973).

Due to the overlap in the morphologic characteristics of the skull elements measurements are mainly used to separate species. The proportion of length to width of the p4 is a good criterion and is shown in fig. 10. For comparison the middle-sized $R$. euryale, which is most similar with $R$. mehelyi, is included in the diagram. Both species can be clearly separated by the scatter plots.

The bone bar, as the most characteristic feature, shows greater variability as supposed by Schober \& Grimmberger (1998). In some skulls it is likewise broad as in $R$. euryale, but the length of the skull is much larger than in the Mediterranean Horseshoe Bat. After SAPPER (1997) morphologic characteristics of both species are not as precise as biometric comparisons. Therefore importance was attached on the metrics and the larger skulls are assigned to $R$. mehelyi.

The great variety of both species makes the 

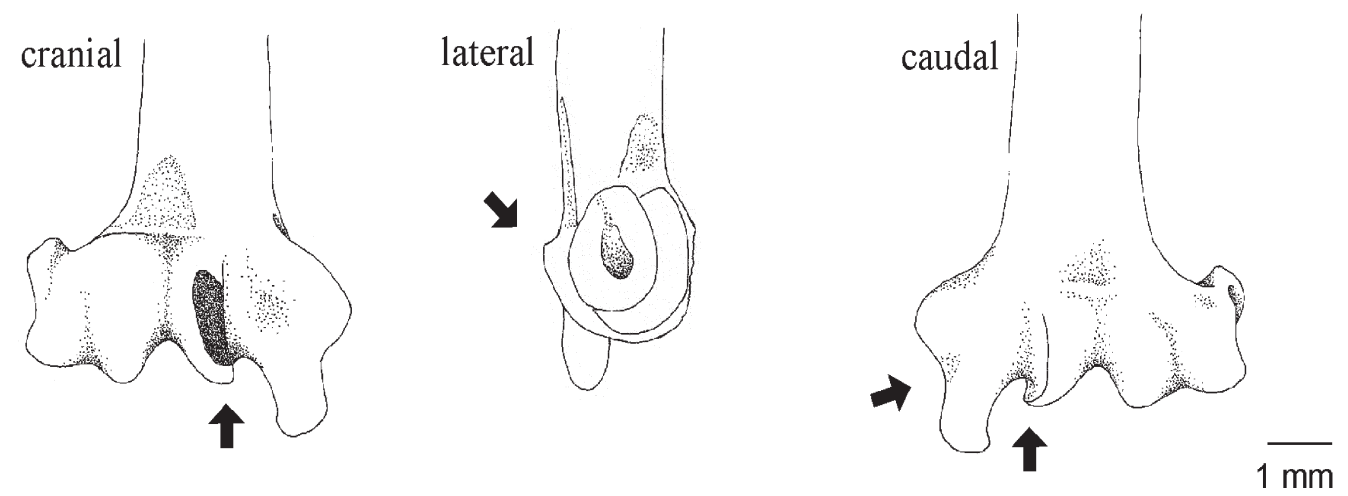

Fig. 9: Distal epiphysis of the humerus of Rhinolophus mehelyi (Yar 1032) in cranial, lateral, and caudal view.

Abb. 9: Distale Epiphyse des Humerus von Rhinolophus mehelyi (Yar 1032) in cranialer, lateraler und caudaler Ansicht.

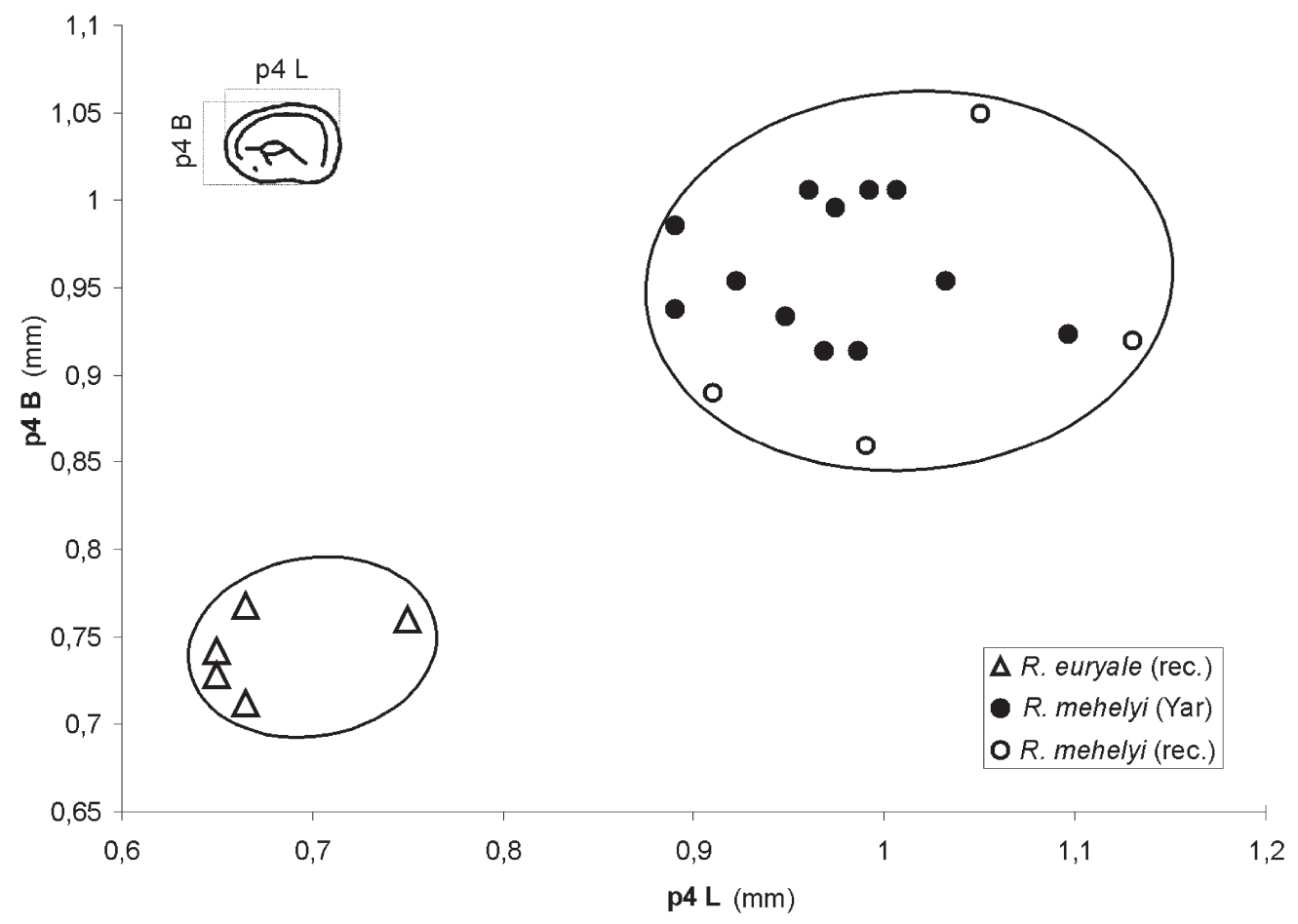

Fig. 10: Comparison of Rhinolophus mehelyi and Rhinolophus euryale on the basis of length and width of the p4.

Abb. 10: Vergleich von Rhinolophus mehelyi und Rhinolophus euryale anhand von Längen-/Breitenmaßen des p4. 
determination of the humerus much more difficult. $R$. euryale reaches similar dimensions as $R$. mehelyi and even the combination of several morphological characteristics makes a definite classification impossible. This material will be combined to a "group Rhinolophus euryale-mehelyi" and discussed.

\section{group Rhinolophus euryale-mehelyi}

cycle I: 35 humeri

There is overlap in the morphology distal epiphysis of the humerus. Especially in the proc. styloides which shows large variation. Its distal peak can be laminar broadend, medial flattend or waisted. Often the epitrochlea shows a distinct ridge towards the proc. styloides, which points to $R$. mehelyi, but the caudal outline of the trochlea of the same humerus is shallow rounded, which points to $R$. euryale. Felten et al. (1973) give dimensions for differentiation, but they had not enough individuals to register the whole variety of the species (pers. comm. G. STоRсн, SMF). Therefore those values of Felten et al. (1973) can only be taken as benchmarks. The variability of the Yarimburgaz material is shown in fig. 11 by the ratio of the length (measured over the condylus) to the width of the distal epiphysis. However, as $R$. euryale fits in the size-spectrum of $R$. mehelyi a separation is impossible.

Vespertilionidae GRAY I82I, Vespertilionid Bats

The Vespertilionidae have a world wide distri-

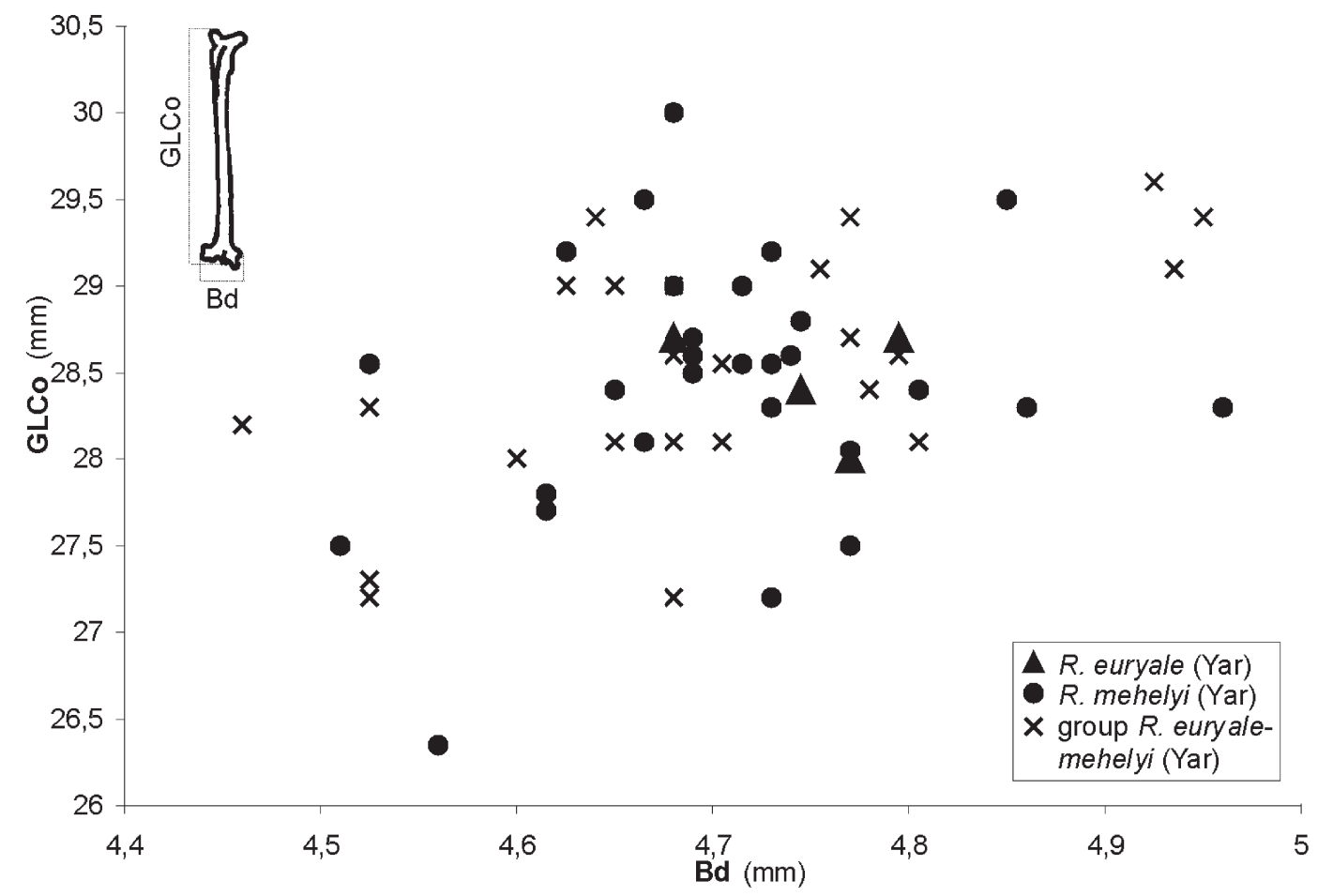

Fig. 11: Comparison of Rhinolophus euryale and Rhinolophus mehelyi on the basis of the humerus. GLCo: greatest length measured over the condylus, $\mathrm{Bd}$ : width of the distal epiphysis, measured perpendicular to the shank axis.

Abb. 11: Vergleich von Rhinolophus euryale und Rhinolophus mehelyi anhand des Humerus. GLCO: größte Länge gemessen über den Condylus, Bd: Epiphysenbreite distal, senkrecht zur Schaftachse gemessen. 


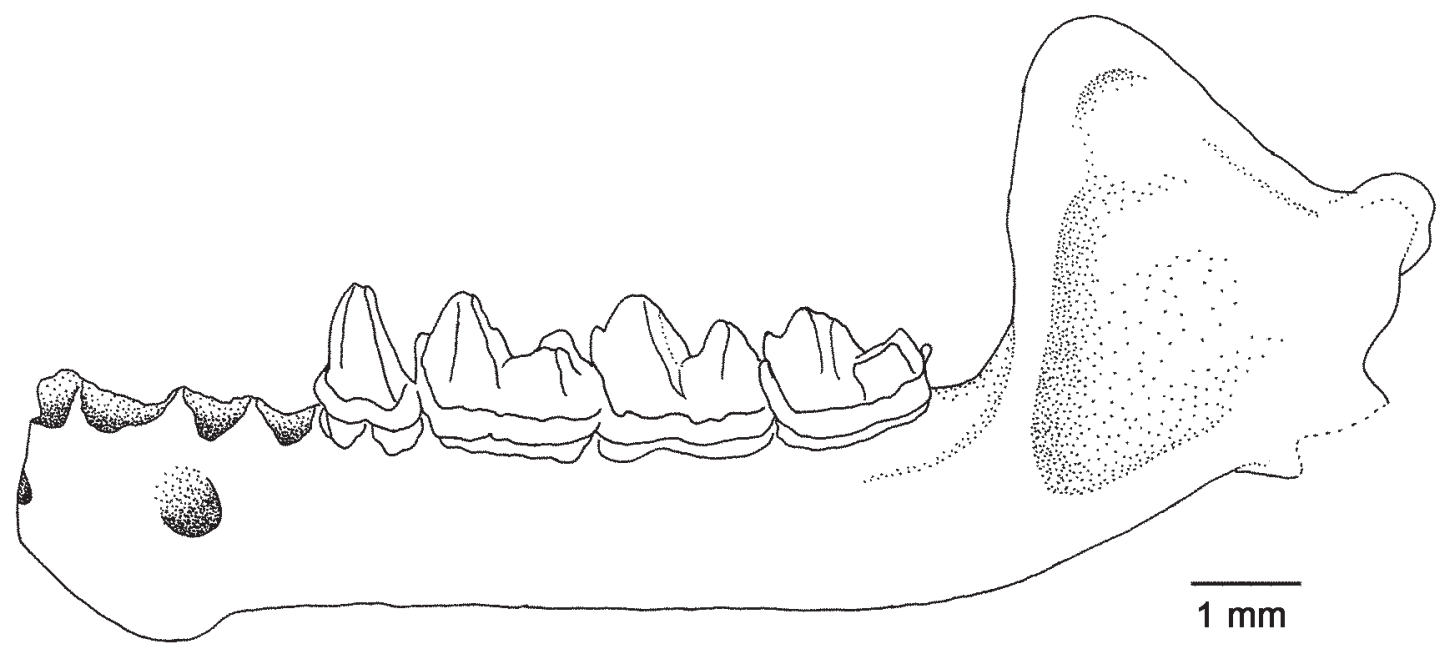

Fig. 12: Mandible of Myotis bechsteini (Yar 31) in lateral view.

Abb. 12: Mandibel von Myotis bechsteini (Yar 31) in Lateralansicht.

bution with 35 genera and 308 species (KoopMANN, 1994). They are found in the tropics as well as in temperate zones up to the tree line. They are distributed in the most northern and the highest areas found within the chiropterans. Many species from the temperate areas migrate between summer- and winter roosts depending. In the Yarimburgaz Cave this could be demonstrated for the genera Myotis, Plecotus, and Miniopterus.

Usually two incisors are situated on both sides of the intermaxilla of the skull of vespertilionids. The incisura nasalis lies deep in the premaxilla and reaches to the canine, maximum to the first premolar. There is no bulb of the nasal region as in rhinolophids. The lower jaw is characterized by a high and compact proc. coronoideus (fig. 12).

Myotis Kaup 1829, Little Brown Bats

Within the chiropterans Myotis is the most widespread form being not found only in the arctic, subarctic and antarctic regions as well as on many oceanic islands (NowAK, 1994). With 84 recent species this genus are also the most diverse within the bats (Koopman, 1994).
The rostrum of the relatively slender skull is elongated. The inc. nasalis is rounded dorsally. Some species build a crista sagittalis but the linea postorbitalis is never prominent. The for. infraorbitale is situated above the P4/M1 and is separated from the orbita by a broad ossified bar. The cr. masseterica and the fossa masseterica distinctly emerge. The foramen mentale is situated under $\mathrm{c} / \mathrm{p} 1$, rarely under $\mathrm{p} 1$.

The upper incisivi build two to three peaks of nearly the same height. There is a diastema between the I 2 and the caninus. The latter is relatively small but massive and with a sharp distal crista surrounded by a broad cingulum. The P1 and $\mathrm{P} 2$ are tiny, whereas the following P4 nearly reaches the height of the $\mathrm{C}$ and surmounts the peaks of the molars. The molars are dilambdodont and lack any peculiar characteristics.

The lower incisors are closely spaced with small overlap. They are spatulate; their crowns develop three to four peaks. The $\mathrm{i} 3$ is significantly larger than i1 or i2 and forms a pronounced inner protuberance. The $\mathrm{c}$ is slightly curved backwards. A bucco-distal and a lingual ridge build a concave distal plane. The $\mathrm{p} 4$ is the tall- 


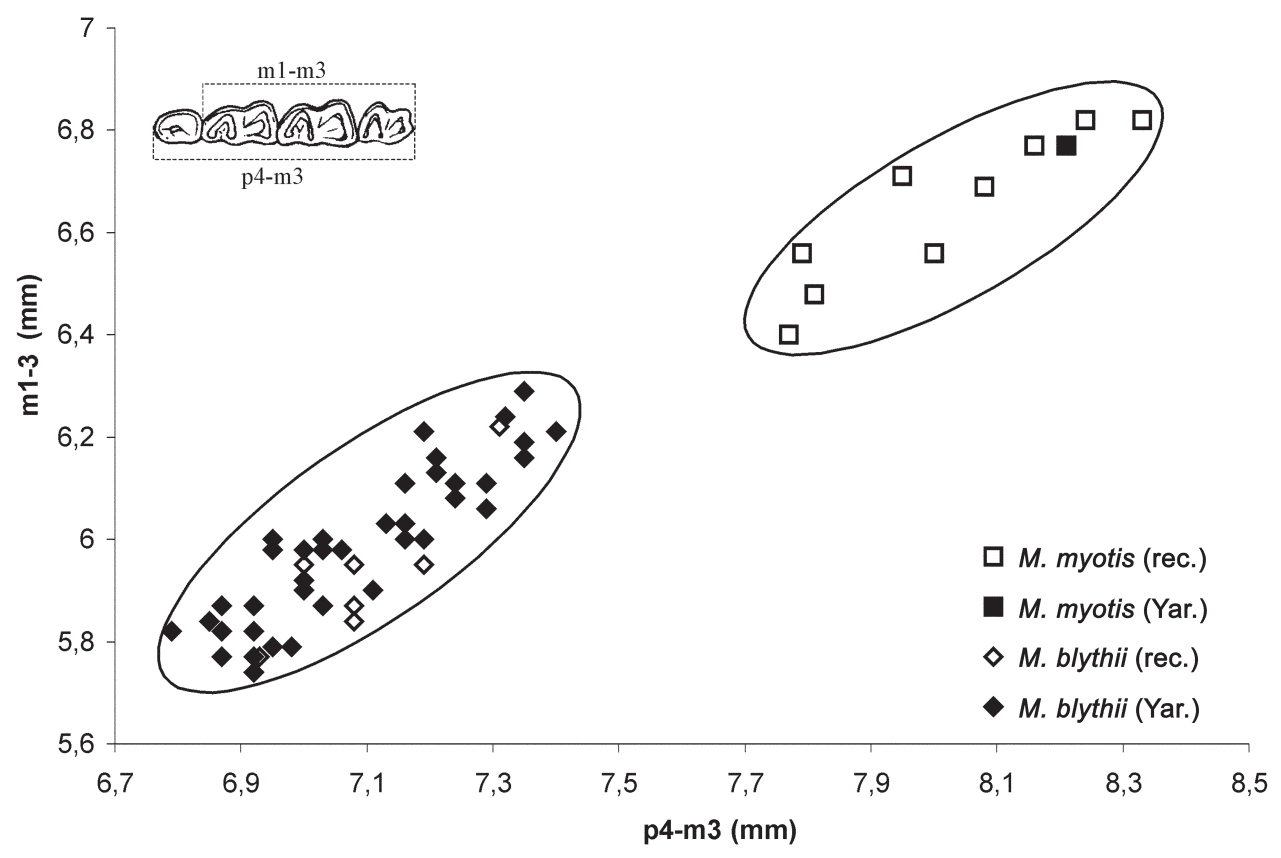

Fig. 13: Comparison of Myotis myotis and Myotis blythii on the basis of the lower tooth row.

Abb. 13: Vergleich von Myotis myotis und Myotis blythii anhand der unteren Zahnreihe.

est premolar in both upper and lower jaw. The molars show myotodont morphology, which means that hypoconulid and hypoconid are not connected.

Concerning the distal epiphysis of the humerus in cranial view the transition from the trochlea to the condylus is slightly convex at the proximal edge of the joint. The proc. styloides hardly surmounts the trochlea or can even be absent. The caudal depression where the olecranon fits in is developed weakly or missing.

Myotis myotis (Borghausen 1797), Mouseeared Bat

uncorrelated: 3 maxillae, 1 mandible

In the upper jaw the P3 is shifted buccally outside the tooth row and therefore not easily visible. The M3 is strongly reduced and consists only of the mesial part of the tooth. Also in the lower jaw the $\mathrm{m} 3$ reduces its distal part, so the talonid is only weakly developed.

In cranial view, the trochlea of the humerus sur- mounts the proc. styloides distally. The width of the distal epiphysis is about 4-4,6 mm (Felten et al. 1973)

The similarity between $M$. myotis and $M$. blythii, which renders a morphological separation of these two species difficult, will be discussed below.

Myotis blythii (Thomes, 1857), Lesser Mouseeared Bat

cycle I: 8 rostra, 8 maxillae, 102 mandibles, 50 humeri; cycle II: 2 humeri; cycle III: 3 rostra, 17 maxillae, 64 mandibles, 55 humeri; surface: 4 mandibles, 7 humeri; uncorrelated: 4 rostra, 26 maxillae, 260 mandibles, 51 humeri

The skull and skeleton of $M$. blythii is very similar to that of $M$. myotis. The obvious difference between these species is that $M$. blythii has smaller dimensions as indicated by their common name. There are only a few minor morphological differences.

The P3 of M. blythii is aligned with the tooth 


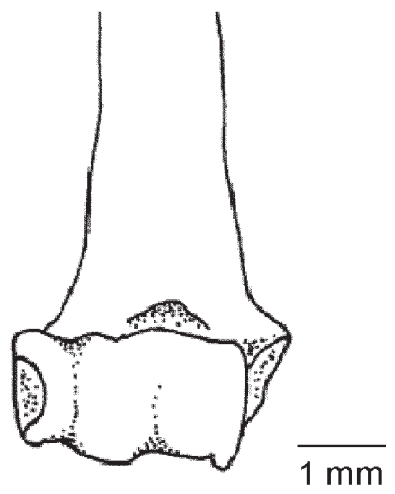

Fig. 14: Distal epiphyisis of the humerus of Myotis bechsteini (Yar 1202) in cranial view.

Abb. 14: Distale Epiphyse des Humerus von Myotis bechsteini (Yar 1202) in Cranialansicht.

row in more individuals than in $M$. myotis. However this feature is very variable and not diagnostic. Nevertheless they can be distinguished by relation of the upper and lower tooth row (fig. 13). The fourth premolar from the Greater Mouse-eared Bat is much larger than the fourth premolar of the Lesser Mouse-eared Bat. No separation of the humeri was possible. Based upon the percentage of abundance $(M$. myotis $0,8 \%$; M. blythii 99,2\%) the humeri are assigned to the Lesser Mouse-eared Bat.

Myotis bechsteini (KuHL 1817), Bechstein's Bat cycle I: 33 mandibles; cycle II: 2 humeri; cycle III: 1 maxilla, 2 mandibles; uncorrelated: 1 rostrum, 13 maxillae, 94 mandibles, 1 humerus The P1 of the upper jaw is as large as or larger than the P3, and the latter is situated within the tooth row. There is often a diastema between P3 and P4. Additional cones, called protocoluli, can be found at the mesial inner plane of M1-3. If they are present, they are only weakly developed. The proc. coronoideus of the lower jaw is very high, its cr. masseterica nearly arises at right angle (fig. 12).

The distal epiphysis of the humerus can easily be identified by the missing proc. styloides (fig. 14). In cranial view the rostral end of the trochlea does not reach the rostral end of the epitrochlea proximally. The width of the epiphysis of 2,9-3,1 $\mathrm{mm}$ is a further characteristic of the relatively large species (FELTEN et al. 1973). In fig. 15 the lower tooth row of the Bechstein's Bat from Yarimburgaz is compared with recent and Early Pleistocene material from DeutschAltenburg (DA 28) of this species. As the fossil record of DA 28 fits in the variability of Yarimburgaz there is no variation of size since the Early Pleistocene. The recent values do not cover the amplitude of variation.

Myotis nattereri (KuHL 1817), Natterer's Bat uncorrelated: 2 maxillae, 2 mandibles

The arcus zygomaticus of the skull is slender (fig. 16a). In lateral view the first two upper incisive diverge, causeing a relatively large angle between both tooth crowns. The $\mathrm{C}$ is comparatively small. The $\mathrm{P} 1$ is insignificantly larger than the following P3; both are highly reduced. Regarding the upper teeth, the $\mathrm{c}$ of the lower jaw is relatively small and the proportion of $\mathrm{p} 1$ to $\mathrm{p} 3$ is concordant with that of the upper jaw (fig. 16a). The cross section of the $c$ is oval.

As there are no specific characteristics of the middle-sized humeral epiphysis (2,6-2,7 $\mathrm{mm}$ ) (Felten et al. 1973). M. emarginatus and $M$. daubentoni are of equal size and thus no humeri of these dimensions could be referred to a specific species.

There is a lot of overlap in morphological and biometrical characteristics of $M$. nattereri with M. emarginatus which will be discussed later.

Myotis emarginiatus, (GEOFfroy 1806), Geoffroy's Bat

cycle I: 1 rostrum, 1 maxilla; uncorrelated: 5 mandibles

The arctus zygomaticus is clearly broadened in lateral view (fig. 16b). The crowns of the incisivi are parallel. The $\mathrm{C}$ is long and acuminate. The $\mathrm{P} 1$ and $\mathrm{P} 3$ are reduced, the $\mathrm{P} 3$ reaches maximum half of P1 (fig. 16b). M1-3 develop no protoconuli. The $\mathrm{i} 2$ of the lower jaw develops four peaks and a further inner conulus can be 


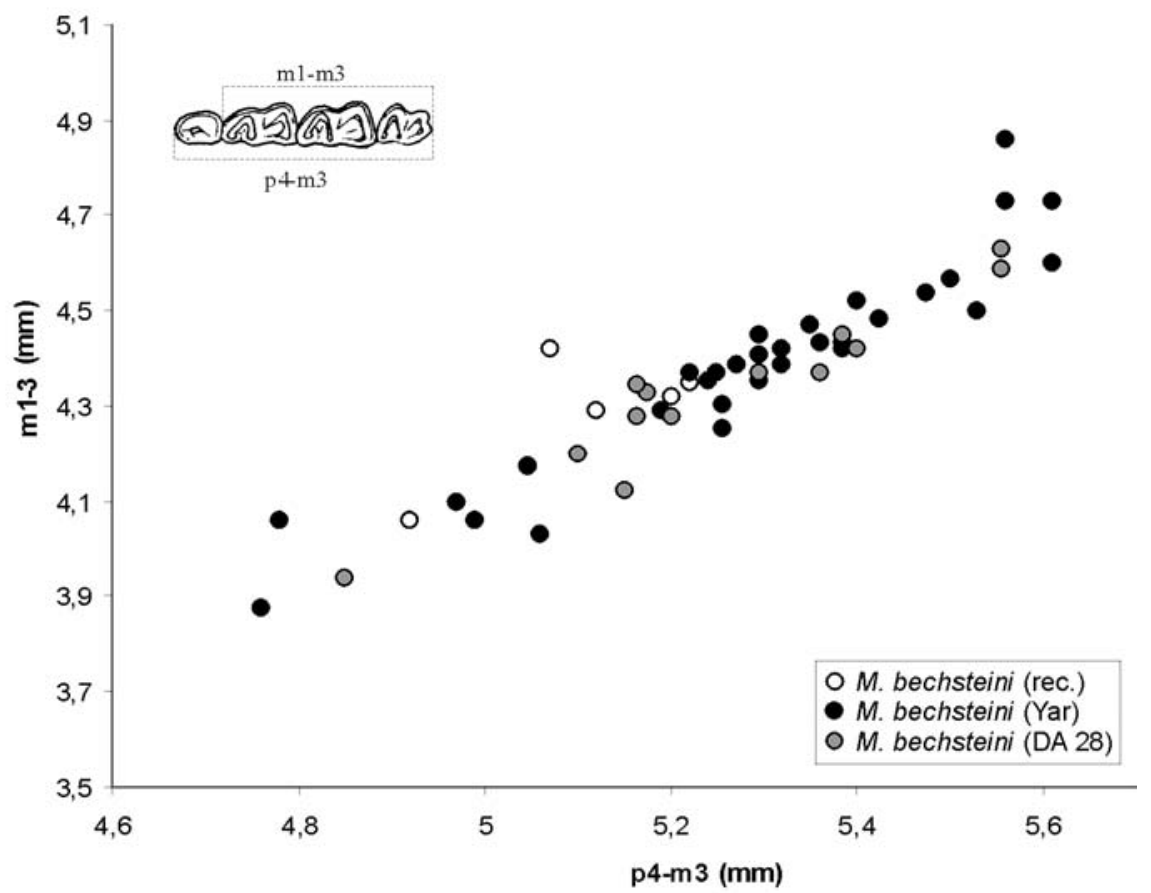

Fig. 15: Comparison of the dimensions of Myotis bechsteini of Yarimburgaz with recent (rec.) and Early Pleistocene representatives (DA 28: Deutsch-Altenburg 28) of the species.

Abb. 15: Größenvergleich von Myotis bechsteini aus Yarimburgaz mit rezenten (rec.) und altpleistozänen Vertretern (DA 28: Deutsch-Altenburg 28) der Art.
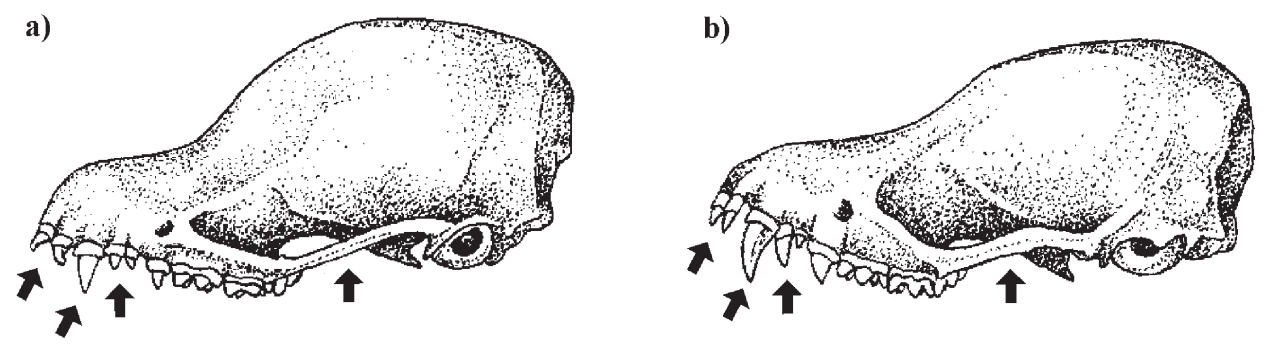

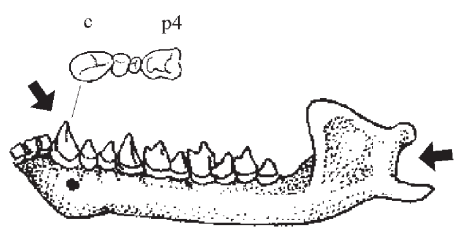

Myotis nattereri

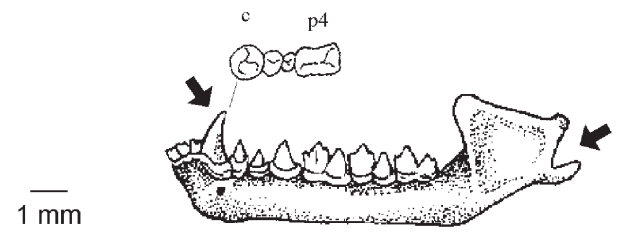

Myotis emarginatus

Fig. 16: Comparison of the skulls of a) Myotis nattereri and b) Myotis emarginatus (after SCHOBER \& Grimmberger 1998).

Abb. 16: Schädel von a) Myotis nattereri und b) Myotis emarginatus im Vergleich (nach ScHOBER \& Grimmberger 1998). 
present. The cross section of the large $c$ is round. The $\mathrm{p} 1$ is slightly larger than the p3 (fig. 16b). As mentioned before there are no characteristics which can be attributed to the humerus.

\section{group Myotis nattereri-emarginatus}

cycle III: 1 mandible; uncorrelated: 4 mandibles

Because of the great variation in individual features, a separation of these two middle-sized species can only be done by a combination of multiple characteristics. The width of the zygomatic arch is a good criterion as well as the morphology of the $\mathrm{C}$ and the proportions of the first upper premolars (fig. 16). The lower jaws can be distinguished by the morphology of the i2 and the c. Unfortunately the front teeth which are often the most important characteristics are missing in the Yarimburgaz material. Metric data could also not be used for differentiation because of the large amount of variability present. Thus, specimens that could not be referred to a species unambiguously were combined into a single group.

\section{group Myotis mystacinus-brandti-daubentoni} uncorrelated: 1 maxilla, 6 mandibles

The corresponding material shows distinct characteristics of the genus Myotis and using morphological measurements it can only be referred to one of the small-bodied species $M$. mystacinus, $M$. brandti, or $M$. daubentoni. These species are very similar to each other in size and morphology and thus a separation of the fragmentary material is not possible.

Myotis capaccinii (BonAPARTE 1837), Longfingered Bat

cycle I: 1 mandible, 6 humeri; cycle III: 2 humeri; surface: 1 humerus; uncorrelated: 11 mandibles

The arcus zygomaticus is slender and similar to that of $M$. nattereri. The first two incisive diverge but not as strongly as in $M$. nattereri. The $\mathrm{C}$ is rather compact. The P4 is significantly larger than the tiny $\mathrm{P} 1$ and $\mathrm{P} 3$ and it reaches across the peaks of the molars. In the mandi- ble the i1 and i2 are three-coned; i3 developed four peaks and is substantially widened. The $\mathrm{c}$ is only weakly developed. As in the upper jaw the crown of the p4 overtops the peaks of the other teeth.

In lateral view the proc. styloides protrudes caudally above the shank of the humerus (fig. 17). A distinct groove, which curves from caudal to lateral, separates the proc. styloides from the trochlea. Another distinguishing feature is the small size of the humerus with an epiphyseal width of 2,7 mm (FELTEN et al. 1973).

The material referred to $M$. capaccinii also comprises a very small humerus that shows the characters described above but has an epiphyseal diameter of only $2.38 \mathrm{~mm}$. This humerus most likely belongs to a juvenile animal.

Plecotus Geoffroy, 1818, Old World Longeared Bats

This genus is distributed in Europe, Asia, North-Africa and America (Kanada to Mexico) with eight recent species (KoopmanN, 1994; NowaK, 1994).

The profile of the skull is relatively flat; the frontal region is mildly bulged. A distinct cr. lacrimalis is situated on the rostral edge of the orbita. The bullae tympanic are large; the distance between them is considerably smaller than their individual diameter. With the reduction of one premolar the dental formula is $2 / 3,1 / 1,2 / 3,3 / 3$. The first of the two upper incisivi is considerably larger and buccally has a further conus. Usually a diastema is situated between the highly reduced P1 and the P4. The cingulum of the latter can build a mesio-lingual protoconus. The molars show no diagnostic features except for the greatly reduced M3. Within the mandibular dentition the inicivi have three to four peaks and the i3 is slightly widened. The pronounced cingulum of the $c$ is mesial extended and builds an additional protuberance on half level of the tooth height. The p3 is narrowed by the $\mathrm{p} 1$ and $\mathrm{p} 4$. The morphology of the molars is myotodont (fig 4). 


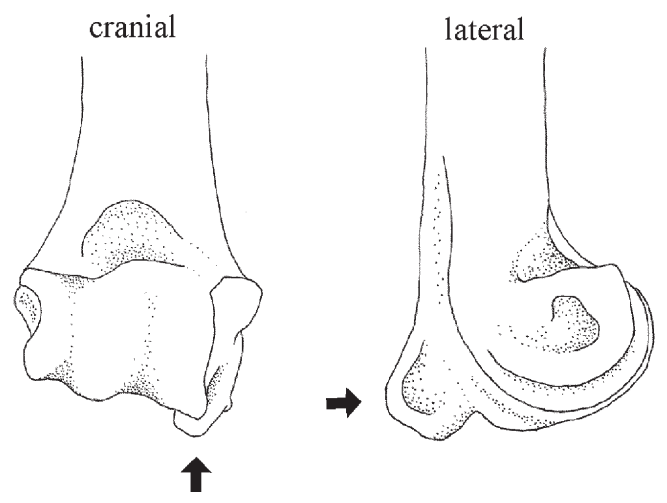

caudal (slightly turned

towards lateral)

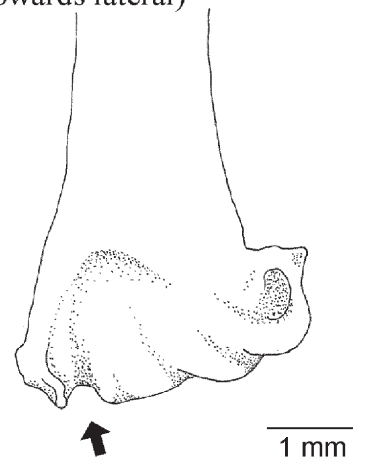

Fig. 17: Distal epiphysis of the humerus of Myotis capaccinii (Yar 1162) in cranial, lateral, and caudal (slightly turned towards lateral) view.

Abb. 17: Distale Epiphyse des Humerus von Myotis capaccnii (Yar 1162) in cranialer, lateraler und caudaler (leicht nach lateral gedreht) Ansicht.

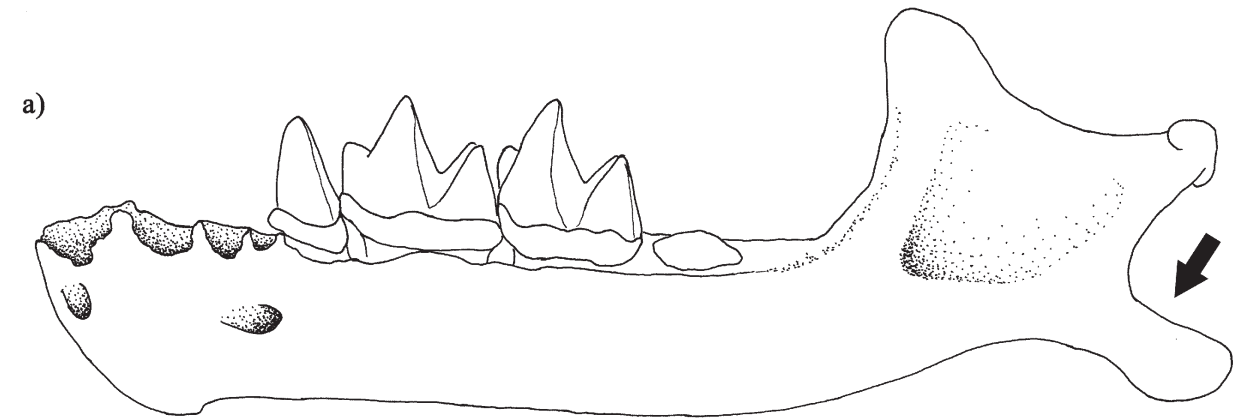

Plecotus auritus

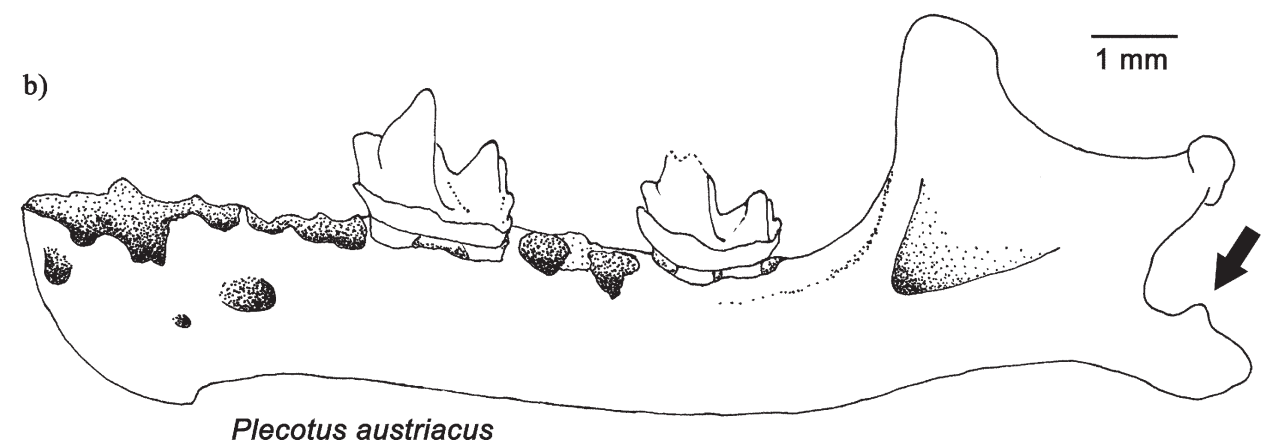

Fig. 18: Comparison of the mandibles of a) Plecotus auritus (Yar 159) and b) Plecotus austriacus (Yar 218).

Abb. 18: Vergleich der Mandibeln von a) Plecotus auritus (Yar 159) und b) Plecotus austriacus (Yar 218). 
In cranial view the transition of the trochlea to the condylus at the distal epiphysis of the humerus is clearly convex at the articulated joint. In the same view the rostral edge of the trochlea does not reach the rostral edge of the epitrochlea. Trochlea and condylus overtop the proximal peak of the epicondylus in lateral view. Caudally the fossa olecrani is not present or only weakly developed.

Plecotus auritus (Linnaeus 1758), Brown Bigeared Bat

uncorrelated: 1 maxilla, 1 mandible

The most prominent feature of the skull is the arcus zygmaticus, which is highly bulged in its middle. The $\mathrm{C}$ is rather short. The lower jaw can be identified by the thickened and rounded end of the proc. angularis (fig. 18a). Similar to the upper jaw the $\mathrm{c}$ is relatively short.

At the distal epiphysis of the humerus the transition of the epitrochlea to the proc. styloides is angular (fig. 19a). The average width of the epiphysis is about 2.7-2.9 mm (Felten et al. 1973).

Plecotus austriacus (Fischer 1829), Gray Bigeared Bat

uncorrelated: 4 mandibles

The arcus zygmaticus on the skull is slightly broadened in its middle but it becomes significantly slender towards aboral. The $\mathrm{C}$ is more slender and more pointed than in $P$. auritus. The proc. angularis at the lower jaw ends blunt with a distinct projection at its anterior third (fig. 18b). The c shows a shallow bending towards distal.

The transition of the epitrochlea to the proc. styloides at the distal epiphysis of the humerus is not as angular as in P. auritus in caudal view (fig. 19b). The average width of the epiphysis is also about 2.7-2.9 mm (Felten et al. 1973).

\section{group Plecotus auritus-austriacus}

cycle III: 1 maxilla, 1 mandible, 1 humerus; uncorrelated: 1 maxilla, 29 mandibles, 4 humeri The differences these two species are very marginal. The diagnostic characters described above are mainly based on structures which are prone to damage during the fossilization process. Other characters, in particular the distal epiphysis of the humerus, are variable and cannot be used on its own (fig. 19). The shape of the proc. angular of $P$. auritus often appears in $P$. austriacus as personal observation of comparison material revealed. Therefore, it is not possible to precisely separate the species.

Miniopterus Bonaparte 1837, Long-winged Bats

Thirteen species of this genus are distributed world-wide except for America and the arctic

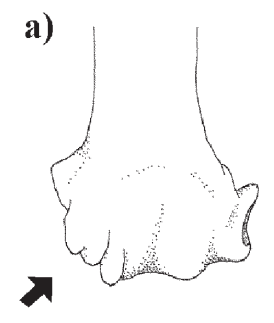

Plecotus auritus

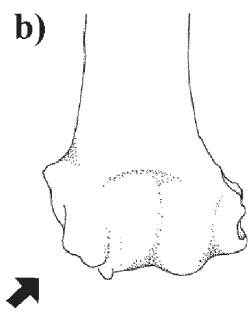

Plecotus austriacus

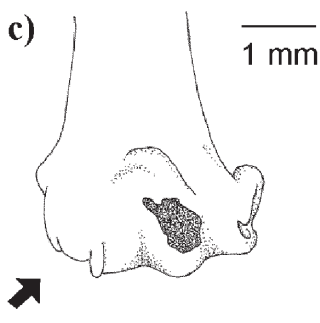

Plecotus sp.

Fig. 19: Comparison of the distal epiphysis of the humerus of a) Plecotus auritus (SMF 32961), b) Plecotus austriacus (SMF 19925) and c) Plecotus sp. (Yar 1182) in caudal view.

Abb. 19: Vergleich der distalen Epiphyse des Humerus von a) Plecotus auritus (SMF 32961), b) Plecotus austriacus (SMF 19925) und c) Plecotus sp. (Yar 1182) in Caudalansicht. 


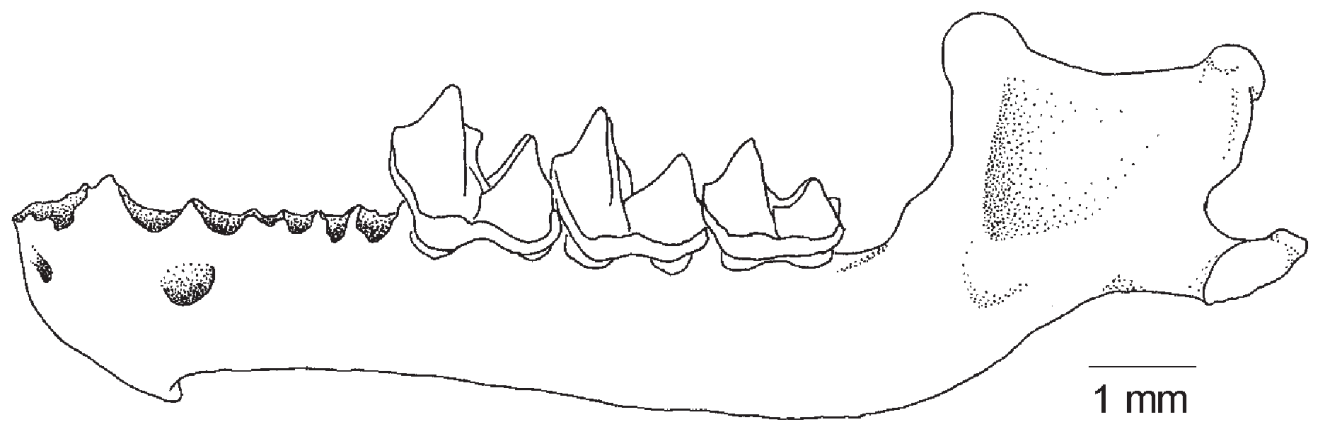

Fig. 20: Mandible of Miniopterus schreibersi (Yar 1199) in lateral view.

Abb. 20: Mandibel von Miniopterus schreibersi (Yar 1199) in Lateralansicht.

regions (Koopman, 1994). In Europe a single species, Miniopterus schreibersi, occurs.

The skull is relatively compact. The rostrum is short and flattened, the frontal region rises steeply. The brain capsule is widened, bulged and outlined from the occiput by a depression. The mandibles are slender and have a remarkable low proc. coronoideus (fig. 20). The proc. articularis is expanded towards medial; also the proc. angularis is widened.

The dental formula is $2 / 3,1 / 1,2 / 3,3 / 3$. The I1 has two peaks and reaches the same height as the following I2. After a broad diastema the very slender $\mathrm{C}$ overtops the tooth cusps of the remaining teeth. The M3 is enormously reduced. The lower incisive are packed close together and increase in size from i1 to i3. The p1 and p3 are reaching same height. As a specialty of this genus the p3 builds two roots instead of one as usual by vespertilionids. The molars are nyctalodont.

The proc. styloides of the distal epiphysis of the humerus is most striking. It protrudes widely beyond the articulated joint and is strongly broadened in lateral view. Additionally, the epiphysis exhibits a deep constriction between condylus and epicondylus.

Miniopterus schreibersi (KuHL 1819), Schreibers's Long-fingered Bat

cycle I: 16 mandibles, 7 humeri; cycle III: 20 mandibles, 25 humeri; surface: 5 humeri; uncorrelated: 1 rostrum, 9 maxillae, 54 mandibles, 28 humeri

The P1 is slightly shifted out of the tooth row towards lingual. It reaches half the height of the succeeding P4. The crown of the latter overtops the peaks of the molars by far. The relatively weakly developed c of the lower jaw is just slightly higher than the $\mathrm{p} 4$ or the molars.

The humerus can be determined with some certainty by the characteristic shape of the distal epiphysis. Additional to these the epiphysis is relatively narrow with an average width of 2.7 mm (Felten et al. 1973).

\section{Composition of the bat fauna}

Three sedimentary cycles were differentiated by Howell \& Arsebük (1989) and Farrand \& McMahon (1997). A rich bat fauna originates from cycles I and III and each of these units is summarized here. The denoted number of the taxa is the minimal number of individuals (MNI) of lower jaws identified. For Rhinolophus euryale the humeri were counted because there were no mandibles (fig. 21). Due to the fact that there is a lot of overlap in the characteristics of Myotis mystacinus, M. brandti, and M. 
daubentoni, these species were grouped together as a self-contained taxon. Other groups are not mentioned here because they occur as a single species.

In cycle I eight species ( $R$. ferrumequinum, R. euryale, R. blasii, R.mehelyi, M. blythii, M. bechsteini, M. capaccinii, and Miniopterus schreibersi) are represented by 375 mandibles (figs. 21, 22). The most frequent taxa are R. mehelyi (57\%), M. blythii (27\%), and M. bechsteini (9\%).

Cycle II produced only a single mandible of $R$. mehelyi.

In cycle III a MNI of 46 belonging to six taxa (R. ferrumequinum, R.mehelyi, M. blythii, M. bechsteini, group $M$. mystacinus-brandtidaubentoni, and Miniopterus schreibersi) is identified with M. blythii (67\%), Miniopterus schreibersi (19\%), and R. mehelyi (8\%) as the most common ones (figs. 21, 22).

In addition, square $U$ offered a great number of fossil bat remains which cannot be precisely correlated to these cycles and are handled separately here.

The genus Myotis is represented by seven to nine species. However, the most frequent species is Rhinolophus mehelyi which represents 52\% of the total sample of bats (fig. 21).

\section{Stratigraphic position of the three cycles and trench $U$}

No exact stratigraphic position can be given for the three cycles. The excavation levels were designated into lithostratigraphic units based on different layers of erosion (fig. 2). The classification was made on the basis of sequence stratigraphy, being a group of sedimentary beds bounded by unconformities. These unconformities can be erosional or non-depositional surfaces, which are indicative of a temporal hiatus in the depositional history (FARRAND \&

\section{McMahon i997).}

Uranium-series dating which was conducted on pure tufa in square Z-88 which suggests an age of $>350 \mathrm{Ky}$, but no exact level indication was given for the sample (Farrand \& McMahon 1997). Electron spin resonance dating (ESR) was made on some ursid tooth samples which points to an approximate age estimate of at least ca. 400 Ky (Farrand \& McMahon i 1997). Also here details on stratigraphic background are missing. The age of the three cycles cannot be determined by the remains of the Microchiroptera. There are no specific index species; all taxa are still present in this part of the Mediterranean.

Cycle I begins with sorted and stratified quartz sand and pebbles, followed by smooth clays. Large limestone blocks from the cave ceiling fell into these from time to time. On the top phosphatic concretions can be found. A Middle Pleistocene age can be assumed because of Cricetus cricetus and Cricetulus migratoris (Santel \& Koenigswald 1998). Most of the bats that can be allocated stratigraphically come from this cycle. Of the eight verified species, R. mehelyi dominates.

The second cycle is characterized by variegated clay with scattered quarz. There are almost no fossils, neither bats or other small mammals, only very few remains of bigger mammals.

The third cycle contains rock fragments with very little matrix. It is probably a result of earthquakes during a short time span (FARRAND \& MCMAHON 1997). The small mammal fauna described by SANTel \& Koenigswald (1998) indicates a Middle Pleistocene age, with younger or older Middle Pleistocene being less probable.

There is no stratigraphical correlation for trench U because this square was very shallow and soon reached bedrock so it could not be separated in stratigraphic units. It is unfortunate that most of the bat fauna was recovered from this trench, since its precise stratigraphic level is uncertain. 


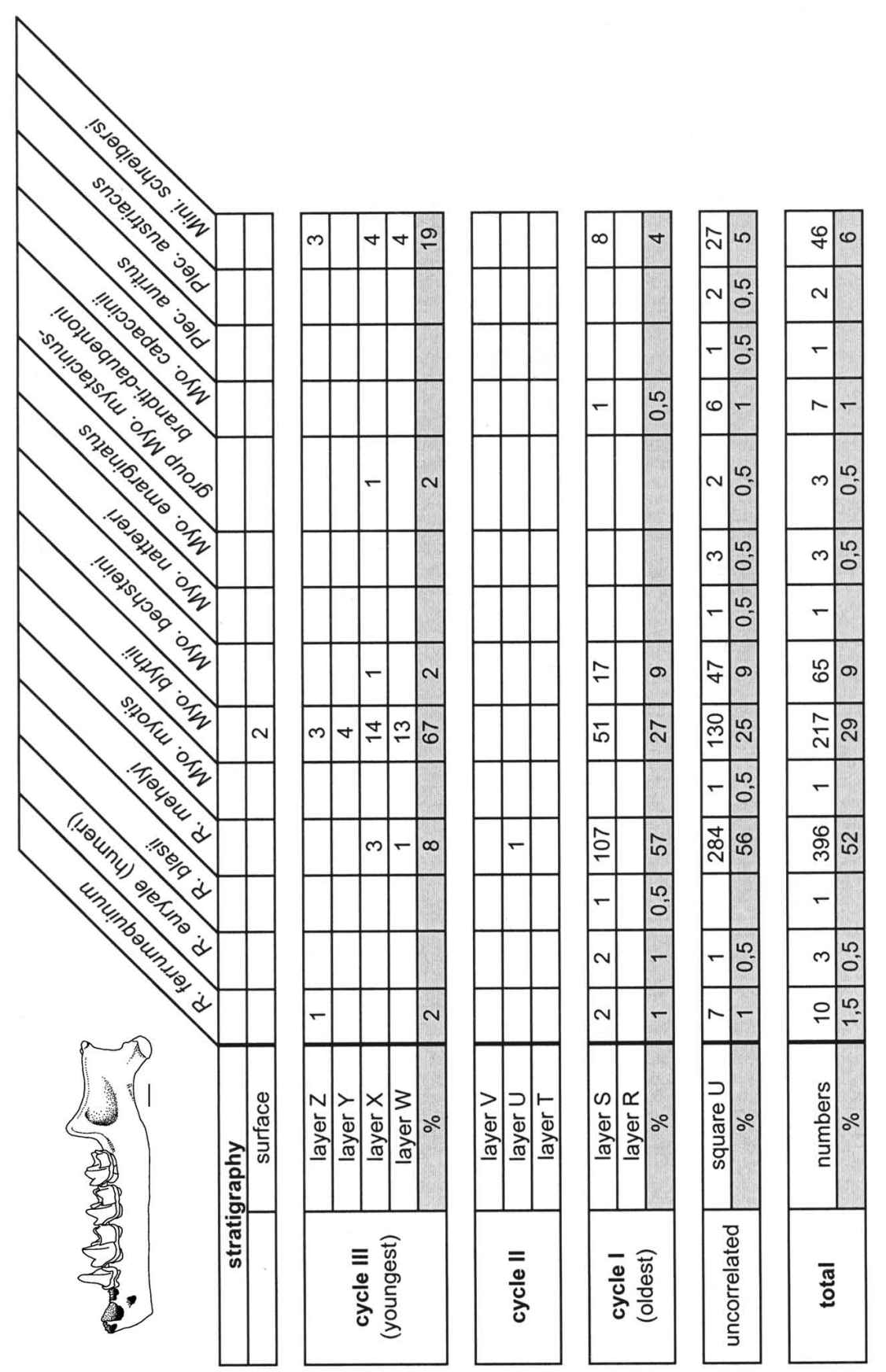

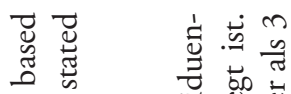

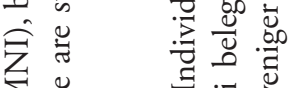

$\sum \infty_{0} \quad \overline{0}$

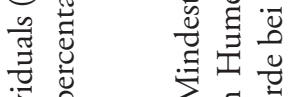

닐

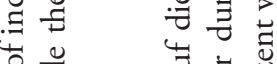

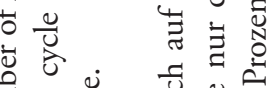

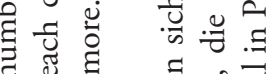

สี้

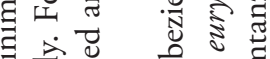

घี ปี

ป न :

○ छ छ 完

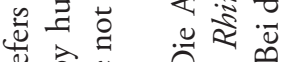

合苛

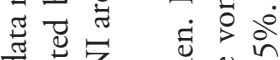

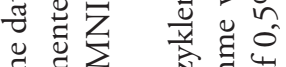

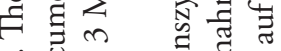

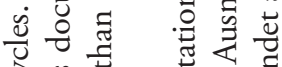

ㄴ.

는

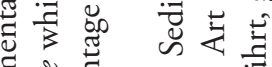

छั ปี

हैं

क ई ह

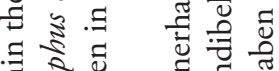

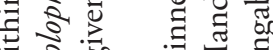

इ का

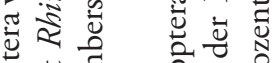

䒘䒘刍 弟元

寻苍记苋

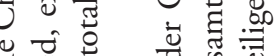

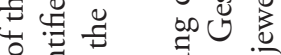

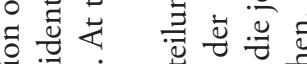

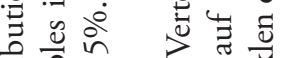

: 0 \&

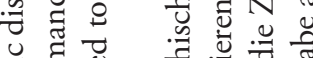

记 चु

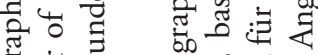

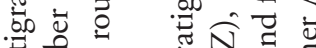

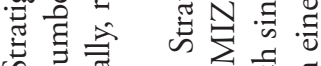

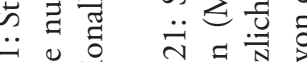

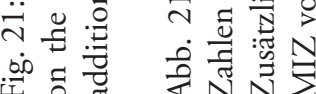




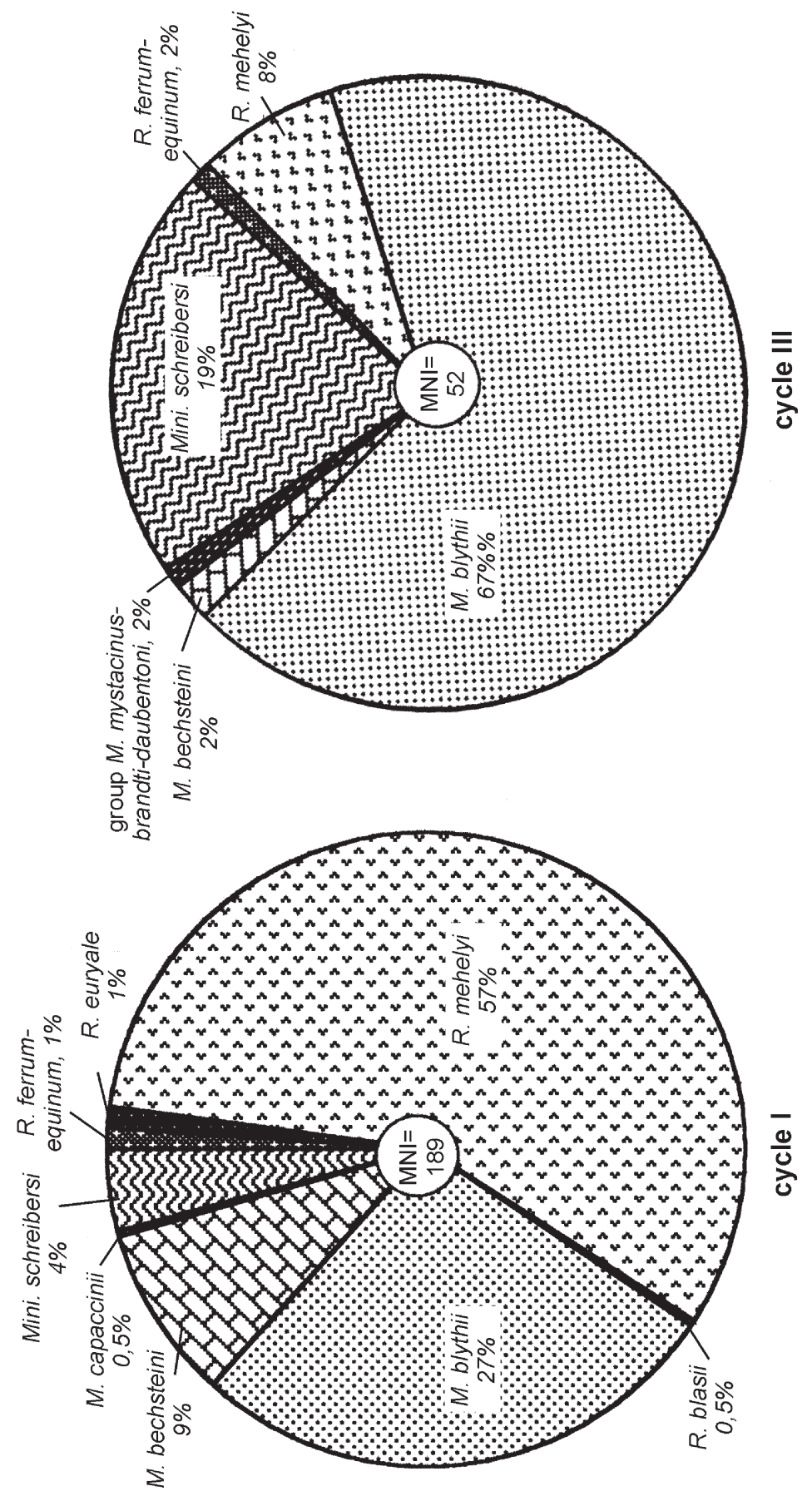




\section{Ecological conditions during}

\section{the three cycles}

As explained above Rhinolophus mehelyi is the most frequent species in the first cycle (figs. 21, 22). It is of ecological significance since it occurs only in warm Mediterranean climate today (Lanza \& Finotello i985; Mitchell-Jones et al. 1999). Its frequent occurrence indicates that the climate during cycle I was not colder than today, but typical Mediterranean. The coexistence of the second species Miniopterus schreibersi as a typical thermophilic taxon supports this assumption due to its recent distribution in the Mediterranean but also in south Asia, Australia, and Africa (RABEDER 1972; LANZA \& Finotello 1985).

Most species, except Myotis bechsteini, prefer open habitats. As a tree-dweller, M. bechsteini probably used the Yarimburgaz Cave only for hibernation. From the residual small mammal fauna analyzed by Santel \& Koenigswald (1998) Cricetus cricetus is the only species indicating a more continental and drier environment. But as the Black-bellied Hamster is found only in layer $S$ it is not significant. In conclusion, an open landscape with bushes and some trees can be postulated for most of the time represented by the bats from cycle I.

From cycle II only one lower jaw of $R$. mehelyi was found, therefore no ecological conclusion can be drawn.

In cycle III six different taxa could be identified from 95 mandibles with $M$. blythii being the most frequent one (figs. 21, 22). Since all of the documented taxa are present in the extant fauna of Turkish Thrace no difference from the present-day climate is indicated by the bat fauna. However, the rodent and lagomorph fauna indicates a dryer, more open landscape and a cooler climate than today (SANTEL 1994). The significant steppic influence is indicated by immigrants from the Ukraine which are no longer found in the area today: Cricetus cricetus, Cricetulus migratoris, Lagurus transiens, Sicista subtilis, and Ochotona pusilla. Although the rodents characterize a harsher climate than the bats, there is no indication that the bats come from other layers than the rodents. Most likely the chiropterans as well as rodents and lagomorphs coexisted in the area. Comparing the recent distribution of these species with that of the chiropterans, all taxa share parts of their ranges. Only the two thermophilic species R. mehelyi and M. schreibersi do not fit in the same ecological surrounding nor overlap in geographic range with Cricetus cricetus, Lagurus transiens, and Ochotona pusilla (EuQUAM; LANza \& Finotello 1985). Therefore, one has to assume that these bats used the cave seasonally and came here in summer only or used it for hibernation. Santel (1994) postulated an open landscape for cycle III with a significant steppic influence. The bat fauna represents an open landscape too, but not as cold and dry. The time involved in cycle III might represent a heterogeneous climate with changing colder, dryer, and warmer phases which is not fully deducible from the coarse stratigraphic allocation of the fossil material. Due to changes in the climate the history of the bat distribution might be characterized by a local extinction and reinvasion of taxa which cannot be determined from the sediments of the Yarimburgaz Cave.

\section{Trench U}

The sediments of the isolated square $\mathrm{U}$ could not be correlated with one of the three cycles because it was very shallow over bedrock and its stratigraphy not informative as mentioned before (Howell \& ArsebüK i989; Farrand \& McMahon 1997). Almost 70\% of the bats originate from this square. Interestingly the majority of the other small mammals (78\%) was also concentrated within square U (SANTEL 
1994). Looking at the map (fig. 1) this huge concentration within a single square seems not to reflect the biotope. As Yarimburgaz Cave is still an active karst-system it may be possible that the small mammals were concentrated by transportation mixed up by various sources. The uninformative stratigraphy made a correlation to any layer of the other squares impossible. Presumably the accumulation of bats represents different time periods which could not be separated during excavation. Therefore, these very rich layers cannot be contributed to the reconstruction of the climatic history of the Yarimburgaz Cave. 13-15 species of bats were identified: Rhinolophus ferrumequinum, $R$. euryale, $R$ mehelyi, Myotis myotis, M. blythii, M. bechsteini, M. nattereri, M. emarginatus, group M. mystacinus-brandti-daubentoni, M. capaccinii, Plecotus auritus, P. austriacus, and Miniopterus schreibersi. In the quantitative distribution, $R$. mehelyi (56\%), M. blythii (25\%), and M. bechsteini (9\%) are predominant (figs. 21, 22).

\section{Summary}

The chiropterans from Yarimburgaz Cave are significant as it is the richest Middle Pleistocene bat fauna of the Eastern Mediterranean found to date. Nine to eleven additional chiropteran species are recorded for that short time of this area, five had been mentioned previously (Santel \& Koenigswald i998). They document the composition of the modern faunal assemblage. Although the bats seem to be of little stratigraphical importance they provide new ecological information, since they may indicate a much milder climate than the rodents and lagomorphs from the same layer. The seasonal migration common for various bats may have allowed some to populate Turkish Thrace only during summer. Thus species indicating a somewhat warmer climate were preserved together with species which characterize a distinctly cooler steppe environment. Because bats are known to migrate it is postulated that some species like Rhinolophus mehelyi and Miniopterus schreibersi were only occasional residents during that period.

\section{Acknowledgements}

Special thank goes to Prof. Dr. W. v. KoenigsWALD, Institut für Paläontologie, Universität Bonn, for his support of this project and fruitful discussions. I also like to thank Dr. G. SтоRCH, Forschungsinstitut Senckenberg, Frankfurt a. M., Dr. R. Hutterer, Zoologisches Forschungsinstitut und Museum Alexander Koenig, Bonn, and Prof. Dr. G. Rabeder, Universität Wien, Austria, for the allocation of comparative material and inspiring discussions. Prof. Dr. K. Rose, Johns Hopkins University, Baltimore, USA, kindly improved the English of this paper. Mr. G. OlesCHInsKi provided the photographic work. I also like to thank the two unknown reviewers for their kindly revision of this paper and their helpful references.

\section{Literature}

EuQuam (European Quaternary Mammalia Database), Institut für Paläontologie, Bonn. Farrand, W. R. \& McMahon, J. P. (1997): History of the sedimentary infilling of Yarimburgaz Cave, Turkey. - Geoarchaeology: An international journal, 12 (6): 537-565; New York.

Felten, H., Helfricht, A. \& Storch, G. (1973): Die Bestimmung der europäischen Fledermäuse nach der distalen Epiphyse des Humerus. - Senckenbergiana Biol., 54 (4/ 6): 291-297, 19 Figs.; Frankfurt a. M. 
Gebhard, J. (1997): Fledermäuse. - 381 S.; Basel (Birkhäuser).

Görner, M. \& Hackethal, H. (1988): Chiroptera. - In: Görner, M. \& HACKETHAL, H. Säugetiere Europas, (Hrsg.): 72-129; Stuttgart (Enke).

Howell, F. C. \& Arsebük, G. (1989): Yarimburgaz Cave, Report on investigations and current status of researches in the cave of Yarimburgaz (Marmara, Turkey) 1989 Field season. - 1-75 + VIII, 22 Figs., 36 Tab., 37 Taf., Committee on Research and Exploration, National Geographic Society; Washington D.C.

Koopman K. F. (1994): Chiroptera: Systematics. - 224 S., 192 Abb.; Berlin (de Gruyter).

Kowalski, K. \& Ruprecht, A. L. (1981): Order: Bats - Chiroptera. - In: Pucek, Z. (ed.): Keys to Vertebrates of Poland, Mammals: 101-154, 25 Abb.; Warschau (Polish Scientific Publishers).

Kryštufek, B. \& Vohralík, V. (2001): Mammals of Turkey and Cyprus. Introduction, Checklist, Insectivora. 140 S.; Knjižnica Annales Majora, Zgidivubsko društo za južno Primorsko, Znansteveno-raziskovalno središče Republike Soovenije Koper, 2001.

Kunn, S. L. (1995): Preliminary Report on Lithic Assemblage from Yarimburgaz Cave, Turkey. - Unpublished manuscript in possession of the authors.

Lanza, B. \& Finotello, P. L. (1985): Biogeografia dei Chirotteri italiani. - Boll. Mus. Reg. Sci. Nat. Torino, 3 (2): 389-420; Firenze.

McKenna, M. C. \& Bell S. K. (2000): Mammal Classification. - Unitaxon,. Mathemaesthetics; New York.

Mitchell-Jones, A. D., Amori, G., Bogdanowicz, W., Krystufek, B., Reijnders, P. J. H., Spitzennberger, F., Stubbe, M.,
Thissen, J. B. N., Vohralik, V. \& Zima, J. (1999): The Atlas of European Mammals. - 496 S.; London (Academic Press).

Nowak R. M. (1999): Walker`s Mammals of the World. - 836 S.; Baltimore (Johns Hopkins University Press).

Özdogan, M. \& Koyunlu, A. (1986): Yarimburgaz Magarasi. 1986 Yili Calismalarinin ilk Sonuçlari ve bazi gözelemer. - Arkeolojìve Sanat, 32/33: 4-17; Istanbul.

Rabeder, G. (1972): Die Insectivoren und Chiropteren (Mammalia) aus dem Altpleistozän von Hundsheim (Niederösterreich). Ann. Naturhistor. Mus. Wien, 76: 375-474, 8 Abb., 14 Taf.; Wien.

Ruprecht, A. L. (1987): A key for mandible identification of Polish bats (polnisch). - Przegl. Zool., 31: 89-105, 47 Abb.; Bialowieza.

Santel, W. T. (1994): Die mittelpleistozänen Insectivora, Chiroptera, Rodentia und Lagomorpha (Mammalia) aus der Yarimburgaz Höhle, westlich von Istanbul (Türkisch Thrazien). - Dipl.-Arb.: 163 S.; Bonn (unveröff.).

Santel, W. T. \& Koenigswald, W. v. (1998): Preliminary report on the Middle Pleistocene small mammal fauna from Yarimburgaz Cave in Turkish Thrace. - Eiszeitalter u. Gegenwart, 48: 162-169, 2 Fig.; Hannover.

Schober, W. \& Grimmberger, E.: (1998): Die Fledermäuse Europas. - 265 S.; Stuttgart (Kosmos).

Stiner, M. C. (1995): Taphonomy and Zooarchaeology of the Large Mammals from Yarimburgaz Cave. - Unpublished manuscript in possession of the authors.

Storch, G. (1974): Quartäre Fledermaus-Faunen von der Insel Malta. - Senckenbergiana lethaea, 55 (1/5): 407-434; Frankfurt a.M. 